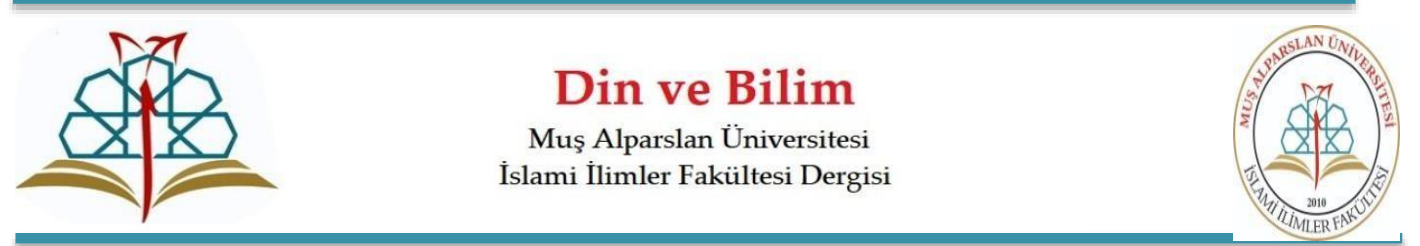

Din ve Bilim - Muş Alparslan Üniversitesi İslami İlimler Fakültesi Dergisi

Region and Science - Journal of Muş Alparslan University Faculty of Islamic Sciences e-ISSN: 2667-7717 Aralik/December 2021, 4(2): 214-234

\title{
Metindilbilimsel Bir Analiz: Kalem Sûresi'nde Eşdizimler
}

A Textlinguistic Analysis: Collocations in Surah Al-Qalam

\section{Fatih SARI}

Öğretim Görevlisi, Muş Alparslan Üniversitesi, İslami İlimler Fakültesi, Arap Dili ve Belâgatı Anabilim Dalı / Lecturer, Muş Alparslan University, Faculty of Islamic Sciences, Department of Arabic Language and Rhetoric, Muş/Turkey

fatihsari.3504@gmail.com

ORCID: 0000-0002-9516-1813.

\section{Makale Bilgisi I Article Information}

Makale Türü / Article Type: Araştırma Makalesi / Research Article

Geliş Tarihi / Date Received: 11 Kasım / November 2021

Kabul Tarihi / Date Accepted: 22 Aralık / December 2021

Yayın Tarihi / Date Published: 31 Aralık / December 2021

Yayin Sezonu / Pub Date Season: Aralık / December

DOI: $10.47145 /$ dinbil.1022433

Bu makale, "Kalem Sûresi'nin Bağlaşıklık Ögeleri Açısından Tahlili” (İzmir Katip Çelebi Üniversitesi, Sosyal Bilimler Enstitüsü, 2020) başlıklı yüksek lisans tezimden üretilmiştir. This article is extracted from my master's thesis entitled "Analysis of Surah al-Qalam in Terms of the Cohesions”, (Master's Thesis, İzmir Katip Çelebi University, Muş/Turkey, 2020).

Atıf / Citation: Sarı, Fatih. "Metindilbilimsel Bir Analiz: Kalem Sûresi'nde Eşdizimler / A Textlinguistic Analysis: Collocations in Surah Al-Qalam". Din ve Bilim - Muş Alparslan Üniversitesi İslami İlimler Fakültesi Dergisi 4 / 2 (Aralık 2021): 214-234. doi: 10.47145/dinbil.1022433

İntihal: Bu makale, iThenticate yazılımınca taranmıştır. İntihal tespit edilmemiştir.

Plagiarism: This article has been scanned by iThenticate. No plagiarism detected. web: https://dergipark.org.tr/tr/pub/dinbil I mailto: dinbil@alparslan.edu.tr

Copyright $@$ Published by Muş Alparslan Üniversitesi, İslami İlimler Fakültesi / Muş Alparslan University, Faculty of Islamic Sciences, Muş, 49250 Turkey.

Bütün hakları saklıdır. / All right reserved. 
Öz

Dilbilimin bir dalı olan metindilbilim, metinleri bir bütün olarak ele almayı hedeflemekte ve metin olan ile metin olmayanı birbirinden ayıran çeşitli ölçütler ileri sürmektedir. Bu ölçütlerden biri olan bağlaşıklık, birtakım ögelerle sağlanmaktadır. Bunlar; gönderim, değiştirim, eksiltili yapı, bağlama edatları ve sözcüksel bağlaşıklıktır. Bunlardan sözcüksel bağlaşıklık, tekrar/yineleme ve eşdizimlerle sağlanmaktadır. Eşdizim ise, birbirleriyle sıkça kullanılan ve aralarında anlamsal bağ bulunan söz birliktelikleridir. Eşdizimsel yapılar bağlaşıklığı temin etmenin yanı sıra metinlerdeki birtakım durum ve olayları özlü olarak ifade etmeleri yönüyle de anahtar unsurlar olma özelliğine sahiptir. Eşdizimlerin en önemli işlevi, herhangi bir metindeki sözcükler arasında anlamsal yönden uyum ve irtibatı sağlamasıdır. Arap dünyasında Kur'ân-1 Kerim'in bazı sûreleri üzerinde bu türden yapılmış birkaç çalışma bulunmakla birlikte baştan sona bütün sûreleri bu yöntemle ele alan kapsamlı bir çalışma henüz yapılmamıştır. Ülkemizde ise, bazı Türkçe metinler ve klasik Arapça şiirler üzerinde bu yöntemden hareketle yapılmış bazı çalışmalar vardır. Bununla birlikte Türkiye'de Kur'ân sûreleri üzerinde yapılmış bu türden bir çalışma görebildiğimiz kadarıyla yoktur. Bu sebeple bu çalışmada ülkemizdeki dilbilim alanına bir katkı sağlamak ve farklı bir pencereden Kur'ân'a bütüncül bir bakış açısı kazandıran metindilbilimsel yöntemin Kur'ân'a uygulanabilirliğinin ortaya konulması hedeflenmiştir.

Anahtar Kelimeler: Arap Dili ve Belagatı, Dilbilim, Metindilbilim, Bağlaşıklık, Eşdizim.

\begin{abstract}
Textlinguistics, a branch of linguistics, aims to deal with texts as a whole and proposes various criteria that distinguish between text and non-text. Cohesion, one of these criteria, is provided by a number of elements. These; reference, substitution, elliptic structure, connecting prepositions, and lexical conjunction. Of these, lexical cohesion is provided by repetition/ reiteration and collocations. Collocations, on the other hand, are word combinations that are frequently used with each other and have a semantic link between them. In addition to providing cohesion, collocational structures have the feature of being key elements in terms of expressing certain situations and events in the texts concisely. The most important function of collocations is to provide semantic harmony and connection between words in any text. There are some studies based on the textlinguistics method both in the Arab world and in our country. Although there are a few studies of this type on some suras of the Qur'an in the Arab world, a comprehensive study has not yet been carried out that deals with all the surahs from beginning to end with this method. In our country, there are some studies on some Turkish texts and classical Arabic poems based on this method. However, as far as we can see, there is no such study conducted on the Qur'anic surahs/verses in Turkey. For this reason, in this study, it is aimed to contribute to the field of linguistics in our country and to reveal the applicability of the textlinguistic method, which gives a holistic perspective to the Qur'an from a different window, to the Qur'an.
\end{abstract}

Keywords: Arabic Language and Rhetoric, Linguistics, Textlinguistics, Cohesion, Collocation. 


\section{Giriş}

Dilbilimsel araştırmalar XIX. yüzyıla kadar büyük ölçüde felsefe ve edebiyat çalışmaları içinde sürdürülmüştür. Dilbilim, XIX. yüzyılın başlarında dilleri karşılaştırma düşüncesiyle ortaya çıkmıştır. Dilbilimle ilgili en önemli gelişmeler, XX. yüzyılda İsviçreli dilbilimci F. Saussure'ün (1857-1913) "kendi başına ve yalnız kendisi için dili incelemek"1 görüşünün bu alana hâkim olmasıyla birlikte yaşanmış, böylece sınırları belirlenerek bağımsız bir bilim dalı haline gelmiştir. Dilbilim özellikle XX. yüzyıldan sonra seyrini değiştirerek tümce ötesi çalışmalara yönelmiştir. Bu amaca yönelik olarak klasik dilbilimde olduğu gibi tek tek sözcükleri ya da tümceleri ele almak yerine metinleri bütünsel bir yaklaşımla inceleyen bazı teoriler ileri sürülmüştür. ${ }^{2}$ Böylelikle çağdaş dilbilim araştırmalarında tümce ötesi çalışmalara gidilmiş, iletişimin sadece kelime ya da cümlelerle değil, birbiriyle bağlantılı tümcelerden oluşan metinlerle gerçekleşeceği görüşü kabul görmüştür. ${ }^{3}$ Bu durum dilbilimsel çalışmalarda "metin" kavramının yoğunluk kazanmasına ve metindilbilimin doğmasına zemin hazırlamıştır. Tümce ötesi çalışmaların bir sonucu olarak ortaya çıkan metindilbilim, metinleri bütünsel bir yaklaşımla ele almayı ve metinleri biçim, anlam, işlev vb. yönlerden incelemeyi hedeflemektedir. Bu itibarla metindilbilim, bir metni metin yapan ve o metne iletişimsel özellik kazandıran çeşitli ölçütler ileri sürmektedir. Bu ölçütlerden biri olan bağlaşıklık, metinlerin yüzey yapısında yer alan dilbilgisel ögelerin birbirleriyle olan anlamsal ilişkilerini ifade eden ve yansıtan bir terimdir. ${ }^{4}$ Bağlaşıklığın amacı, salt gramatik bir çözümleme olmayıp aynı zamanda bir metni oluşturan söz birimleri arasındaki anlamsal ilişkileri tespit ederek okura bütüncül bir bakış açısı kazandırmaktır. Metinleri oluşturan tümce birimlerini hem dilbilgisel hem de anlamsal açıdan bir bütün haline getiren bağlaşıklık bazı ögelerle sağlanmaktadır. Bu ögeler; gönderim (reference/الإحالة), değiştirim (substitution/الاستبدال), eksiltili yapı (ellipse/الحذف), bağlama edatları (conjunction/أدوات الربط) ve sözcüksel bağlaşıklık (lexical cohesion/الاتساق المعجمي) olmak üzere beş tanedir. Sözcüksel bağlaşıklık ise, tekrar/yineleme (reiteration/التكرير) ve eşdizimlerle (collocation/التضامّ-للصاحبة اللغوية) sağlanır. ${ }^{5}$ Bu ögeler yoluyla cümle ve paragraf dizileri metinsel ve iletişimsel bir özellik kazanır.

Arapça bir metin olan Kur'ân-1 Kerîm gerek lafızlarının dizilişi gerekse içerdiği manâların derinliği açısından üstün bir belagat ve fesahate sahip olan mucize bir kitaptır. Kur'ân'ın i'câz yönünü ortaya koyan en önemli hususlardan biri de lafızları ve manâları arasındaki anlamsal irtibat ve bağlaşıklıktır. İşte bu noktada metindilbilimsel yöntem, Kur'ân'ın lafızlarında yer alan dilbilgisel ögeler arasındaki anlamsal ilişkileri tespit edip içerdiği derin manâları kavramaya ve böylece bütünsel bir bakış açısıyla Kur'ân'ı anlamaya yardımcı olmaktadır. Bu gayeyi gerçekleştirme ve bu amaca hizmet etme gayretleri zamanla meyvelerini vermiş ve neticede Arap dilinin özellikleri, kuralları ve inceliklerini konu edinen, Kur'ân'ın anlaşılması ve yorumlanmasına yardımcı olacak nahiv, sarf, belagat vb. dille ilgili ilimler ortaya çıkmıştır. Bu tür çalışmaların temel gayelerinden biri de Kur'ân'ın dilsel yönünü ortaya koymaktır. Zira Kur'ân sadece ihtiva ettiği derin manâlarıyla değil, aynı zamanda dil incelikleri ve lafızları yönüyle de bir mucizedir. Tefsir ilmi terminolojisinde buna “I'câzü'l-Kur'ân" denilmektedir. Kur'ân'ın lafız, manâ, âyet ve sûreleri arasındaki o mucizevi uyumu

\footnotetext{
${ }^{1}$ Ferdinand De Saussure, Cours de Lingistique Generale/Genel Dilbilim Dersleri, çev. Berke Vardar (İstanbul: Multilingual Yayınları, 2001), 36.

2 Eyup Akşit, "Kur'an-1 Kerim'in Bazı Ayetlerinde Zamir Gelmesi Gereken Yerde İsmin Getirilmesi ve Bunun Nedenleri", Dokuz Eylül Ünüversitesi İlahiyat Fakültesi Dergisi, 48, (Aralık, 2018), 52.

${ }^{3}$ Gülşen Torusdağ-İlker Aydın, Metindilbilim ve Örnek Metin Çözümlemeleri (Ankara: Pegem Akademi Yayınları, 2018$), 67$.

${ }^{4}$ Yusuf Karataș, Söylembilim ve Arapça, (Çanakkale: Onsekiz Mart Üniversitesi İlahiyat Fakültesi Yayınları, 2009), 33.

${ }_{5}$ M.A.K. Halliday-Ruqaiya Hasan, Cohesion in English (London: Longman Group Limited, 1976), 4-6; Torusdağ-Aydın, Metindilbilim, 68.
} 
ortaya koymada bağlaşıklık ölçütü önemli katkılar sağlamaktadır. Burada şunu da hemen belirtmek gerekir ki, bu çalışmada Kur'ân'ın doğru ve bütünsel olarak anlaşılmasındaki tek yolun metindilbilimsel yöntem olduğu şeklinde bir iddia yoktur. Zira Arap dili ekseninde oldukça erken dönemlerde ortaya çıkan belagat, sarf, nahiv, tefsir vb. ilimlerin Kur'ân'ı doğru anlamaya yönelik çabaların temelini oluşturduğu şüphesizdir. Bu makalenin amacı, adı geçen klasik ilimlere nispeten oldukça geç bir dönemde (20. yüzyılda) tekâmüle ulaşmış modern bir bilim dalı olarak metindilbilimin de Kur'ân'ın bütünsel açıdan doğru anlaşılması ve yorumlanmasında sağlayacağı katkıları ortaya koymaktır.

Bağlaşıklık, dilbilimsel araştırmaların gelişmesiyle birlikte 1960'lı yılların ortalarında yeni bir alan olarak karşımıza çıkan metindilbilim dalının metinsellikte aradığı en önemli ölçütlerden biridir. Metindilbilime göre metinlerin oluşturulma amacı, muhatapla iletişim kurarak bilgilendirme yapmak ve okuru etkilemektir. Bu da ancak ilgili metnin bir bütün olarak değerlendirilmesiyle mümkündür. Kur'ân-1 Kerîm açısından bakıldığında bunun karşılığı 'Kur'ân'da bağlam' ifadesidir. Yani herhangi bir konuyla ilgili Kur'ânî nassların siyak ve sibakının dikkate alınarak bir bütün halinde değerlendirilmesidir. Zira iletilmek istenen mesajın muhatap tarafından sağlıklı bir şekilde anlaşılması da ancak bu sayede mümkün olabilir. Kur'ân'a parçacı bir yaklaşım sergileyerek birer birer âyetleri ya da sadece âyetleri oluşturan söz birimlerini ele almak doğru bir Kur'ân anlayışının önüne set çekeceği gibi, nasslar arasında görünürde birtakım çelişki ve uyuşmazlıkları da beraberinde getirecektir. $\mathrm{Bu}$ nedenle Kur'ân nasslarını metindilbilimsel bir bakış açısıyla okuyup anlamaya çalışmak, âyet ve sûrelerin bağlamını dikkate almada önem arz etmektedir. Bu çalışmada, Kur'ân'ın bu yöntemle okunmasının sağlayacağı bazı katkıları dikkatlere sunmak amacıyla Kalem Sûresi, metindilbilimin bağlaşıklık yönlerinden biri olan eşdizimsel örüntüler açısından tahlil edilmiştir.

Sözcüklerin anlamını belirlemede eşdizimsel yapıların önemli bir rolü vardır. Örneğin Türkçe'de sıkça kullanılan "eli açık", "eli sıkı", "eli uzun" vb. ifadelerde "el” sözcüğü, bazı kelimelerle eşdizim oluşturmuş ve birliktelik oluşturduğu sözcüğe göre anlamı değişmiştir. Eşdizimsel yapıların tespiti bir yönüyle de verilmek istenen mesajların etkili ve kalıcı olmasını sağlamaktadır. Özellikle Kur'ân açısından düşünüldüğünde eşdizim oluşturan birtakım anahtar ifadelerin tespiti, bir sûreyi oluşturan âyetler arasındaki anlamsal ilişkilerin ortaya konulması ve ilgili sûrenin konu bağlamında anlaşılması noktasında önemli katkılar sunar. Örneğin Kalem Sûresi'nde geçen أصحاب الجنة (Bahçe sahipleri) tamlaması, tarihi bir hadiseyi iki kelimeden oluşan bir eşdizimle özlü olarak ifade etmekte, ardından gelen yaklaşık on yedi âyet ile de bu ifadenin mahiyeti hakkında bilgi verilmektedir. Yani söz konusu eşdizim, yaklaşık on yedi âyet için çatı bir kavram olmaktadır. Dolayısıyla bir eşdizimsel örüntü yoluyla birçok âyet arasında anlamsal yönden ilişki kurulmuş olmaktadır. Ayrıca bu eşdizim, sûrenin önemli bir konusunu teşkil etmesi sebebiyle konu bağlamında da sûredeki bağlaşıklığı ve bütünselliği sağlamaktadır. Ancak bütün eşdizimler bu şekilde genel ve konu düzeyinde bir özellik taşımaz. Bazı eşdizimler yalnızca içinde yer aldıkları ayet birimleri arasındaki bağlaşıklığı ve bütünlüğü sağlar. Örneğin Kalem Sûresi'nde "fiil+harf-i cer/fiil+ilgeç" formatında yer alan ( ضل عن، غدوا (على ifadeleri bu türden eşdizimlerdir. Bu örnekten de anlaşılacağı üzere, harf-i cerlerle (ilgeçler) bileşik bir yapı oluşturan fiiller de eşdizimsel yapıların bir parçası olarak kabul edilmektedir. ${ }^{6}$ Çünkü söz konusu harf-i cerler, bu fiillerin ayrılmaz birer parçası haline gelmişlerdir. Bu harfler, fiillerin anlamını da etkilemektedir. Örneğin; رغب فistemek, arzulamak" anlamına gelirken, رغب عن "yüz çevirmek, istememek" anlamin ifade etmektedir.

${ }^{6}$ Bilgi için bk. Ferîd Ivaz Haydar, "el-Musâhabetü'l-lafziyye fî şi'ri Şevkî”, Mecelletü külliyeti dâri'l-ulûm, 33, (2004), 574-609; Yaşar Daşkıran, “Arap Dilinde Eşdizim ve Arapça Sözlüklerde Eşdizim Sorunu”, Journal of Islamic Research, 26/1, (Ocak 2016$), 3$. 
Kalem Sûresi'nde yer alan (أصحاب) kelimesinin, Kur'ân'ın çeşitli yerlerinde farklı sözcüklerle benzer birliktelikler oluşturduğunu yani eşdizim olarak kullanıldığını görmekteyiz. Bunlardan bazıları gibi tamlama şeklinde gelen eşdizimlerdir. Görüldüğgü üzere bu kullanımlarda ortak birer kelime bulunmakla birlikte, eşdizim oluşturduğu sözcüğe göre anlamları değişebilmekte ve özel bir anlam kazanabilmektedir. Dolayısıyla gerek Arapça bir metin olan Kur'ân'a gerekse diğer metinlere bu bakış açısıyla yaklaşmanın hem bütünsel anlayışta hem de yorumlamada ciddi bir kolaylık sağlayacağını söyleyebiliriz.

Arap dünyasında metindilbilim alanıyla ilgili birtakım eserler kaleme alınmış, ayrıca bazı Kur'ân Sûreleri ve diğer Arapça metinler üzerinde de metindilbilimsel tahlil çalışmaları yapılmıştır. Bunlardan birkaçı şöyledir: Muhammed Hattâbî, Lisâniyyât en-Nass; Ferîd Ivaz Haydar, elMusâhabetü'l-lafziyye fi şi'ri Şevkî; Ebu Delv, Tahlîlu'l-hitâbi'l-cedelî fìl-Kur'ân: Dirâsetun fì lisâniyyâti'nnass, (Doktora Tezi); Ahmed Afîfî, el-ihâle fì nahvi'n-nass; Celîle Sâlih el-Alâk, Âleyâtü̈l-ittisâki'nnahviyyi ve eseruhâ fi't-temâsüki'n-nassî fì sûreti'l-Beled; Bûşeyhî İlhâm-Kutâf Nebîle, el-İttisâk ve'l-insicâm fì sûreti'l-Kehf; Cemîle Zekrâvî, el-ìttisâk ve'l-insicâm fì sureti Yâ-sin.

Ülkemizde bu konuyla ilgili benzer birtakım çalışmalar bulunmakla birlikte bunlar daha çok Türk dili açısından ele alınmış ve az da olsa Türkçe bazı metinler üzerinde metindilbilimsel tahlillerin yapıldığı çalışmalar kaleme alınmıştır. Bu çalışmalardan bazıları şunlardır: Gülşen Torusdağ-ïlker Aydın, Metindilbilim ve Örnek Metin Çözümlemeleri; Bülent Özkan, Metindilbilimi, Metindilbilimsel Bağdaşıklık ve Haldun Taner'in 'Onikiye Bir Var' Adlı Öyküsünde Metindilbilimsel Bağdaşıklık Görünümleri; Şükran Dilidüzgün, "Türkçe Öğretiminde Metindilbilimsel Bağlamda Uygulamah bir Yaklaşım" (Doktora Tezi); Neticeyi Tayyibe Eken, "Anlatı Metinlerinde Sözcük Birliktelikleri" (Doktora Tezi). Türkiye'de Kur'ân Sûreleri üzerinde yapılmış metindilbilimsel bir çalışma bulunmamakla birlikte bazı klasik Arapça şiirler üzerinde bu türden birkaç makale mevcuttur. ${ }^{7}$ Bizi böyle bir çalışmaya yönelten iki temel neden vardır: Birincisi, metinlerin oluşturulması, anlaşılması ve yorumlanmasında okuyucuya bütüncül bir bakış açısı kazandırdığı düşünülen metindilbilimsel yöntemin Kur'ân'a uygulanabilirliği ve Kur'ân bütünselliği bağlamında ortaya koyacağı sonuçlardır. Bu yönüyle bu çalışma, metinlerin bütünsellik bağlamında ele alınması, parçacı anlayıştan uzaklaşıp bütünsel yaklaşımın esas alınması bakımından önem arz etmektedir. İkincisi de Türkiye'de metindilbilimsel ölçütler açısından Kur'ân Sûreleri üzerinde herhangi bir çalışmanın bulunmayışıdır. Bu sebeple çalışmamızda örnek bir sûre üzerinden konunun önemine dikkat çekilmiştir. Kalem Sûresi'ndeki eşdizimsel örüntülerin sûrenin bağlaşıklığına etkisi ve söz konusu örüntülerin Kur'ân genelindeki kullanımları dikkatlere sunulmuş, bu kelime beraberliklerinin Kur'ân'a bütüncül yaklaşımda taşıdığı öneme vurgu yapılmıştır.

Kalem Sûresi'ndeki eşdizimsel yapılara geçmeden önce, bu tür çalışmalara temel teşkil eden dilbilim alanının tarihi gelişimine, dilbilimin bir dalı olan metindilbilimin doğuşu ve gelişimine ve bağlaşıklık ölçütüne özetle değinerek, bu alanın tarihi serencamını kısaca arz etmeye çalışacağız.

\section{Dilbilimin Tanımı ve Tarihi Gelişimi}

Dilbilim kavramı hakkında çeşitli tanımlamalar yapılmıştır. Dilbilim alanına önemli bir açlım getiren, bu itibarla da çağdaş dilbilimin kurucusu olarak kabul edilen İsviçreli ünlü dilbilimci Ferdinand De Saussure (1857-1913) dilbilimini, "kendi başına ve yalnız kendisi için dili incelemek" 8 şeklinde tanımlamaktadır. Dilbilimini bir 'insan bilimi' olarak gören Fransız dilbilimci Andre Martınet

\footnotetext{
${ }^{7}$ Buna örnek olarak Eyüp Akşit'in “Abdullah b. Revâha'nın Hz. Hamza'nın Şehadetine İlişkin Şiirinde Bağlaşıklık Öğeleri” adlı makalesi zikredilebilir.

${ }^{8}$ De Saussure, Cours de Lingistique Generale/Genel Dilbilim Dersleri, 36.
} 
(1908-1999) ise, "dilbilim, insanin dil yetisini ele alan bilimsel bir incelemedir"9 tanımlamasını yapmaktadır. Dilbilim en genel anlamda "XIX. yüzyılın ortalarında gelişmeye başlayan, son yüzyıl içinde büyük gelişmeler göstererek diller üzerinde çok geniş kapsamlı araştırmalara yol açmış olan ve dillerin yapısını incelemeyi amaç edinen bir bilim dalı"10 şeklinde tanımlanmaktadır. Dilbilim, geleneksel dil bilgisi gibi kurallar koymak yerine, dilsel olguların gözlemlenmesinden yola çıkarak dil dizgesinin eş zamanlı boyutta işleyişini inceleyen, tüm zamanlarda özel ve değişken nitelikler taşıyan doğal dilleri ve bu dillerin zamanla uğradıkları değişimleri araştırma konusu yapan bir insan bilimidir.11 En kısa ifadesiyle dilbilimini "dilin bilimi" veya "dilin bilimsel olarak incelenmesi" şeklinde tanımlamak da mümkündür. ${ }^{12}$

Dil araştırmaları XIX. yüzyıla kadar büyük oranda felsefe ve yazın çalışmaları içerisinde ele alınmış ve dil bu alanların anlaşılmasını sağlayan bir araç olarak kabul edilmiştir. ${ }^{13}$ Dilbilim terimi, ilk kez XIX. yüzyılda dil incelemelerindeki yeni bir yaklaşımı geleneksel filolojiden ayırmak için kullanılmıştır. ${ }^{14}$ Dilbilim her ne kadar yeni bir alan olarak karşımıza çıksa da m.ö. V. yüzyıla kadar uzanan köklü bir geçmişi vardır. Yaklaşık olarak 2500 yıl gibi uzun bir tarihi geçmişten devraldığı ilke ve kavramları tenkide tabi tutarak oluşumunu günümüze kadar devam ettirdiği ifade edilmektedir. ${ }^{15}$ Yeryüzünde dil ile ilgili yapılan çalışmaların bilinen en eski örnekleri, eski Hint ve eski Yunan'a kadar uzanmaktadır. ${ }^{16}$

İslâm kültüründe de dilcilik alanında çok önemli bir ilerleme kaydedilmiştir. VII. yüzyıldan önce de köklü bir dilcilik geleneğine sahip olan İslâm dünyasında bilhassa fonetik, gramer, sözlük bilgisi ve metin şerhleri noktasında derin araştırmalar yapılmış ve Arap dilcileri önemli çalışmalar ortaya koymuşlardır. ${ }^{17}$ İslâm dünyasında da edebi bir kelam özelliği taşıyan Kur'an metni, dilbilimsel açıdan incelemeye tabi tutulmuş, onu açıklama mahiyeti taşıyan ve bir tür dil incelemesi olarak da kabul edilebilecek tefsir çalı̧̧maları yapılmıştır. Bu dönemdeki Arap dilcileri, iştikak üzerinde de durmuş ve bu alanda sözlük çalışmaları yapmışlardır. ${ }^{18}$

Özellikle XVII. yüzyıldaki dilbilim çalışmaları, sonraki yıllarda da etkisini sürdürerek ciddi bir ilerleme kaydetmiştir. Tarihin bütün dönemlerinde dilsel araştırmalara rastlanmakla birlikte dilbilim bağımsız bir dal olma hüviyetiyle ancak XIX. yüzyılın başlarında dilleri birbiriyle karşılaştırma düşüncesiyle ortaya çıkmıştır. ${ }^{19}$ Dilbilim alanındaki en önemli gelişmeler ise, XX. yüzyılda meydana gelmiştir. Bu yüzyılda dilbilimin ivme kazanmasında F. Saussure'ün (1857-1913) önemli bir etkisi vardır. Onun dilbilim ile ilgili "kendi başına ve yalnız kendisi için dili incelemek" 20 görüşünün bu alana hâkim olmasıyla birlikte dilbilimin sınırları belirlenmiş ve bağımsız bir bilim dalı haline gelmiştir. ${ }^{21}$ Dil hakkındaki bakış açılarının farklılığı, çeşitli dilbilim dallarının ortaya çıkmasını sağlamıştır. ${ }^{22} \mathrm{Bu}$

\footnotetext{
${ }^{9}$ Andre Martınet, İşlevsel Genel Dilbilim, çev: Berke Vardar (İstanbul: Multilingual Yayınları, 1998$), 13$.

${ }^{10}$ A. Sumru Özsoy vd., Genel Dilbilim - II (Eskişehir: Anadolu Üniversitesi Web Ofset, 2013), 91-92.

${ }^{11}$ Zeynel Kıran - Ayşe Eziler Kıran, Dilbilime Giriş (Ankara: Seçkin Yayınları, 2006), 110-122.

12 Ahmet Kocaman, Dilbilim Temel Kavramlar Sorunlar Tartışmalar (Ankara: Dil Derneği Yayınları, 2006$), 9$.

${ }^{13}$ Kocaman, Dilbilim Temel Kavramlar, 11.

14 Türkçe Bilgi, “https://www.turkcebilgi.com/dilbilim” (Erişim Tarihi: 01.11.2021).

${ }^{15}$ Kıran - Eziler Kıran, Dilbilime Giriş, 19.

${ }_{16}$ Mehmet Aydın, Dilbilim El Kitabı (İstanbul: 3F Yayınları, 2007), 19; Doğan Aksan, Her Yönüyle Dil -Ana Çizgileriyle Dilbilim (Ankara: TDK Yayınları, 2007), 16.

17 Aksan, Her Yönüyle Dil, 16.

${ }_{18}$ Aydin, Dilbilim, 21.

${ }^{19}$ Berke Vardar, Açıklamalı Dilbilim Terimleri Sözlüğ̈̈̈ (İstanbul: Multilingual Yayınları, 2002), 74.

${ }^{20}$ De Saussure, Cours de Lingistique Generale/Genel Dilbilim Dersleri, 36.

${ }^{21}$ Kocaman, Dilbilim Temel Kavramlar, 11.

22 Ali Abdulvâhid el-Vâfî, İlmü'l-luğa (Mısır: Nehdat-u Misr, 2004), 8-11; Kıran-Kıran, Dilbilime Giriş, 237.
} 
dalların en önemlilerinden biri de metinlerin oluşturulması, açılanması ve yorumlanması hakkında öne sürülen ve çalışmamızı da yakından ilgilendiren metindilbilimdir. ${ }^{23}$

\section{Metindilbilimin Tanımı, Amacı ve Doğuşu}

Metindilbilim, "Dili, cümlelerarası bağlantıları temel alarak inceleyen, dil kullanımını metin üretme olarak gören, metinleri bir bütünlük içinde ele alan dilbilim dalı" olarak tanımlanmaktadır. ${ }^{24}$ Arap dilinde genellikle ilmu lisâniyyati'n-nass (علم لسانيات النّ) terimiyle ifade edilen metindilbilim için ilmu lügati'n-nass

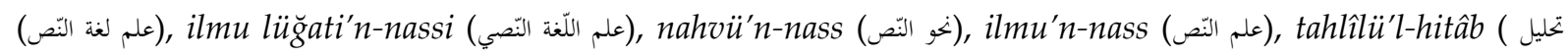
(الخطاب) vb. terimler de kullanılmıştır. ${ }^{25}$ Metindilbilim, yazılı veya sözlü olan bir metni metin yapan, metnin oluşturulmasında kullanılan iç yahut dış yapıyı, zihinde daha kalıcı ve anlaşılır kılmayı sağlayan nitelik ve prensipleri tespite çalışan bir bilim dalıdır. ${ }^{26}$ Metindilbilimin amacı ise, "metinlerin yapılarını, yani dilbilgisel ve içeriksel kurgulanış biçimlerini ve bildirişimsel işlevlerini ortaya çıkarmak ve uygulamalı örneklerle göstermektir." ${ }^{27}$ Böylelikle metindilbilim, herhangi bir metnin inşasının genel şart ve kurallarını tasvir etmeye ve bunların metnin anlaşılması için taşıdığı önemi ortaya koymaya çalışır. Metindilbilim, metne önem verir ve inceleme konusu yaptığı metnin yapısından hareketle onu bağlaşıklık ve bağdaşıklık açısından inceler. ${ }^{28} \mathrm{Bu}$ itibarla metindilbilim kısaca, metinlerin bütünsellik bağlamında incelenmesini konu edinen bilim dalı şeklinde tanımlanabilir. Çünkü metindilbilim, bir metni oluşturan kelime veya söz gruplarını tek tek incelemek yerine, metni oluşturan birimler arasındaki bağlantıları ortaya koyarak söz konusu metni bütünsel bir bakış açısıyla inceleyip açıklamaya çalışır.

Dilbilim alanı özellikle XX. yüzyıldan sonra seyrini değiştirmiş, tümceyi esas alan çalışmalardan ziyade tümce üstü çalışmalara yönelmiştir. Klasik dilbilimde olduğu gibi tek tek cümleleri incelemek yerine metinleri bütüncül bir bakış açısıyla ele alan teoriler üretmiştir. ${ }^{29}$ Böylece modern dilbilim incelemelerinde artık tümce ötesi çalışmalara gidilmiş, iletişimin yalnızca tümcelerle değil, yapısal ve anlamsal olarak birbirleriyle ilişkili tümcelerden oluşan metinler vasıtasıyla gerçekleşeceği anlayışı kabul edilmiştir. ${ }^{30}$ Amerikan dilbilimci Zellig Harris (1909-1992), "Discourse Analysis" (Söylem Çözümlemesi) isimli çalışmasıyla, metnin en büyük dil birimi olarak kabul edilmesi gerektiğini ifade eden ilk dilbilimci olup, dilin dağınık kelime veya tümcelerden ziyade 'bağıntılı bir söylem' şeklinde kullanıldığını belirtmiş ve dilin, gerçekte cümlelerle sınırlandırılmış şekilde değil, söylemler biçiminde kullanıldığını belirtmiştir. Z. Harris (1909-1992), tümce çözümlemesi ifadesi yerine Discourse Analysis terimini kullanmak suretiyle tümce üstü dil araştırmalarında büyük bir adım atmıştır. ${ }^{31}$ İşte Harris'in ortaya attığı bu düşünce ve başka dilbilimcilerin de bu düşünceyi destekleyerek katkıda bulunmasıyla dilbilim seyrini değiştirmiş, tümceyi esas alan çalışmalardan ziyade tümce ötesini esas alan düşünceye yönelmiş ve metinleri bir bütün olarak ele alan teoriler üretmiştir.

\footnotetext{
${ }^{23}$ Dilbilimin diğer dalları için bk. Vardar, Dilbilim terimleri sözlüğ̈̈, 12, 18, 40, 51, 96, 182, 184; TDK, Sözlük (Ankara: TDK Yayınları, 1949), 163; Mehmet Hengirmen, Dil bilgisi ve Dilbilim Terimleri Sözlüğü (Ankara: Engin Yayınları, 1999), 27, 71-72, 316, 339-340; Kâmile İmer vd., Dilbilim Sözlüğ̈̈ (İstanbul: Boğaziçi Üniversitesi Yayınları, 2011), 230.

${ }^{24}$ Hengirmen, Dil bilgisi, 276.

25 İmâran Melîke - Bû Suveyra Vesîle, el-îttisâk ve'l-insicâm fî sûrati'l-Mücâdele: Dirâsetün fî dav'i lisâniyyâti'n-nass, (Becâye: Abdurrahman Mîra Üniversitesi, Yüksek Lisans Tezi, 2016/2017), 22.

${ }^{26}$ Yusuf Alan, Lisan ve İnsan (İzmir: TÖV Yayınları, 1994), 62.

${ }^{27}$ Canan Ayata Şenöz, Metindilbilim ve Türkçe (İstanbul: Multilingual Yayınları, 2005), 22-23.

${ }^{28}$ Melîke -Vesîle, el-İttisâk ve'l-insicâm, 23.

${ }^{29}$ Akşit, "Kur'an-1 Kerim'in Bazı Ayetlerinde Zamir Gelmesi Gereken Yerde İsmin Getirilmesi ve Bunun Nedenleri”, 52.

30 Torusdağ - Aydın, Metindilbilim, 67.

${ }^{31}$ Leyla Subaşı Uzun, Orhon Yazıtlarının Metindilbilimsel Yapısı (Ankara: Simurg Yayınları, 1995$), 18$.
} 
1970'li yıllardan itibaren dilbilimin ayrı bir dalı olarak ortaya çıkan ve metinlerin oluşturulmasında tümce ötesi dil birimleri arasındaki ilişkilerin incelenmesini esas alan metindilbilime ilişkin incelemelerde, birer birer metinlerdeki tümceler değil; metinleri oluşturan dilsel yapılar arasındaki bağıntılarla bir bütün olarak metnin yapısı ve işlevi önem kazanmıştır. Metinleri bu anlayışla ele alan metindilbilim, birbirinden farklı metin türleri arasındaki çeşitli işlevsel ve yapısal özellikleri belirlemeye çalışarak, metinler ile bu metinlerin gönderimde bulundukları olgular arasındaki bağları araştırma konusu yapar. Böylelikle metinlerin çok katmanlı anlamsal yapılarını tespit eder. ${ }^{32}$ Metindilbilim ile birlikte artık geleneksel dil bilgisinin tümce ve kelimelerle sınırlı olan çerçevesinin dışına çıkılmış ve temel dil birimi 'metin' olmuştur. Diğer bir ifadeyle, parçacı yaklaşımdan bütüncül anlayışa geçilmiş ve metni oluşturan dil birimleri arasındaki bağlantıların tespiti yoluyla bir bütün olarak metnin yapısı ve işlevi önem kazanmıştır. Metindilbilim, tümce ötesi dil çalışmalarının esasını teşkil eden dilsel üst yapıları bütüncül bir bakış açısıyla ele alarak kendisine çalışma konusu yapan dilsel bir çalışma sahası olarak günümüzde de gelişimini sürdürmektedir. ${ }^{33}$

\section{Metinsellik Ölçütleri (معايير النصية)}

Metinsellik, bir metni metin yapan birimlerin meydana getirdiği bütündür. ${ }^{34}$ Bir tümce dizisinin metin olabilmesi için birtakım ölçütlere sahip olması gerekmektedir. Metindilbilim açısından metinsellikten söz edebilmek için yedi tür ölçüt ileri sürülmüştür. ${ }^{35} \mathrm{Bu}$ ölçütlerden herhangi biri metinde yer almaz ya da yetersiz olursa o metnin, bildirişim özelliğini ve iletişimsel fonksiyonunu kaybetmesi söz konusudur. ${ }^{36}$ Çünkü metin, metinselliğin bu ölçütlerini ihtiva eden iletişimsel bir oluşumdur. Bir metni metin yapan bu ölçütler şunlardır: Bağlaşıklık (Cohesion/الاتساق),

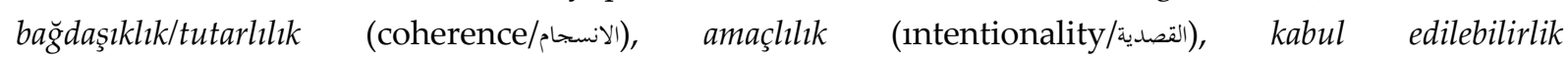

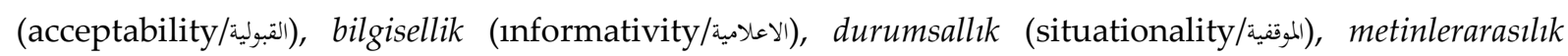

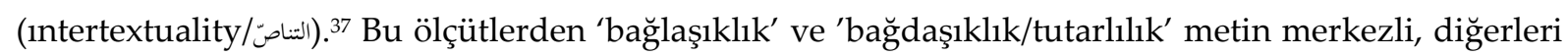
de kullanıcı veya bağlam merkezlidir. ${ }^{38}$ Çalışmayla ilgili olması sebebiyle bu ölçütlerden yalnızca bağlaşıklık üzerinde durulacaktır.

\section{Bağlaşıklık (الاتساق)}

Bağlaşıklık, doğrudan metnin yüzey yapısıyla ilgili olup ${ }^{39}$ herhangi bir metnin yüzeyindeki dilbilgisel ögeler arasındaki anlamsal bağlantıların nasıl kurulduğuyla ilgili metindilbilimsel ölçüttür. ${ }^{40}$ Bu bakımdan bağlaşıklık, metinleri oluşturan söz birimleri ve cümlelerin oluşturulması, zamirlerin kullanımı, ${ }^{41}$ sözcük, söz dizim vb. konuları kapsayan, cümlelerin dilsel bir bütünlük oluşturacak şekilde birbirlerine eklemlenerek bir metin oluşmasını sağlayan ve metin içi bağlantıları

\footnotetext{
32 Torusdağ-Aydın, Metindilbilim, 38.

33 Bülent Özkan, “Metindilbilimi, Metindilbilimsel Bağdaşıklık ve Haldun Taner'in 'Onikiye Bir Var' Adlı Öyküsünde Metindilbilimsel Bağdaşıklık Görünümleri”, Çukurova Üniversitesi Sosyal Bilimler Enstitüsü Dergisi, 13/ 1, (Haziran 2004), 168.

34 Özsoy vd., Genel Dilbilim-II, 156.

${ }^{35}$ R. Alain de Beaugrande - W. Ulrich Dressler, Introduction To Text Linguistics, (London: Longman Linguistics Library, 1981), 113.

36 Torusdağ-Aydın, Metindilbilim, 16; Muhlise Coşkun Ögeyik, Metinlerarasılık ve Yazın Eğitimi (Ankara, Anı Yayınları, 2008 ), 12.

${ }^{37}$ Beaugrande-Dressler, Introduction To Text Linguistics, 113; Torusdağ-Aydın, Metindilbilim, 16.

38 Özsoy vd., Genel Dilbilim-II, 156; Torusdağ-Aydın, Metindilbilim, 16.

39 Torusdağ-Aydın, Metindilbilim, 17.

${ }^{40}$ Karataş, Söylembilim ve Arapça, 33; Ögeyik, Metinlerarasılık, 18.

${ }^{41}$ Karataş, Söylembilim, 33.
} 
kuran dille ilgili özelliklerin tümüdür. ${ }^{42}$ Nitekim bağlaşıklık ölçütü, metni oluşturan tümcelerin birimlerini hem dilbilgisel hem de sözcüksel açıdan iki yönlü olarak birbirine bağlamaktadır. ${ }^{43}$ Böylelikle tümceler bütünsel bir yapı oluşturarak metinsel ve iletişimsel bir özellik kazanır. Bağlaşıklık olgusu, metindeki bir tümceyle onun yorumlanması için lâzım olan diğer bir tümce veya öge arasında anlamsal bir ilişki kurar. ${ }^{44}$ Dolayısıyla bağlaşıklık, herhangi bir metnin yüzey yapısında görülen dilsel özellikler olup, metni oluşturan parçalar arasındaki dilbilgisel bağlantılar bu ölçütle sağlanmaktadır. Başka bir ifadeyle bağlaşıklık, metinlerin somut ve yüzeysel yapısıyla ilgilenen metindilbilimsel bir ölçüttür. Metindilbilime göre, metinlerin yüzey yapısında görülen bağlaşıklık olgusu, çeşitli dilbilgisel araç ve sözcüksel bağlantıyla sağlanmaktadır. ${ }^{45}$ Metinlerde bağlaşıklığı sağlayan ögeler (elements of cohesion/ أدوات الاتساق) şunlardır:46

1) Gönderim (الإحالة)

2) Değiştirim (الاستبدال)

3) Eksiltili Yapı (الحذف)

4) Bağlama Edatları (أدوات الربط)

5) Sözcüksel Bağlaşıklık (داطלات الاتساق المعمي) duracağız.

Biz bu ögelerden yalnızca çalışmamızın konusuyla ilgili olan sözcüksel bağlaşıklık üzerinde

\subsection{Sözcüksel Bağlaşıklık (الاتساق الدعجمي)}

Metinlerde bağlaşıklığı sağlayan bir öge olarak sözcüksel bağlaşıklık, diğer bağlaşıklık ögelerinin tamamından farklılık arz eder. Diğer bağlaşıklık ögelerinde varsayan ya da varsayılan bir unsur söz konusudur. Ancak sözcüksel bağlaşıklıkta böyle bir durumdan söz etme imkânı olmadığı gibi, metindeki unsurlar arasında bağlantı sağlayan biçimsel-dilbilgisel herhangi bir araçtan da bahsedilemez. ${ }^{48} \mathrm{Bu}$ öge, metinlerin küçük ölçekli yapısında yer alan sözlüksel birimlerin kullanımıyla ilgili olup, büyük ölçekli yapıyı (bağdaşıklık) hazırlayan dilbilgisel düzenlemeleri içermektedir. Sözcüksel bağlaşıklık, en genel anlamıla sözcüklerin tekrarı/yinelenmesi demektir. Fakat bu sözcükler aynı bağlamda kullanıldığından dolayı artık birbirleriyle ilişkili duruma gelmiş olmaktadır. Sözcüksel bağlaşıklığın başka bir şekli de birbirleriyle doğrudan bağlantılı olan sözcüklerin eşdizim oluşturmasıdır. ${ }^{49}$ Diğer bir ifadeyle, "sözcüksel bağlaşıklık temelde metin tümcelerinde ayn ögenin tekrarı ve anlamsal olarak ilişkili ögelerin kullanımıyla sağlanan metin bağların içerir." 50 Bu bakımdan sözcüksel bağlaşıklık, tekrar/yineleme (reiteration/التكرير) ve eşdizim (collocation/المصاحبة) olmak üzere iki alt başlıkta ele alınmıştır. ${ }^{51}$ Sözcüksel bağlaşıklığın daha iyi anlaşılabilmesi için biz tekrar/yineleme (reiteration/التكرير/) ögesine kısaca değinip ardından eşdizim konusunu detaylı olarak ele alacağız.

\footnotetext{
${ }^{42}$ Torusdağ-Aydın, Metindilbilim, 17.

${ }^{43}$ Özsoy vd., Genel Dilbilim-II, 156.

${ }^{44}$ Özsoy vd., Genel Dilbilim-II, 156.

${ }^{45}$ Halliday - Hasan, Cohesion in English, 4-6; Torusdağ-Aydın, Metindilbilim, 68.

${ }^{46}$ Bağlaşıklık ögelerinin tasnifi konusunda birbirinden farklı sınıflandırmalar yapılmıştır. Ancak biz bağlaşıklık ögelerini tasnif ederken M.A.K. Halliday ve R. Hasan'ın ortak çalışması olan “Cohesion in English" isimli eserde yer alan sınıflandırmayı tercih ettik. bk. Halliday-Hasan, Cohesion in English, 6.

${ }^{47}$ Halliday-Hasan, Cohesion in English, 6.

${ }^{48}$ Muhammed Hattâbî, Lisâniyyâtü'n-nass: Medhalün ilâ insicâmi'l-hitâb (Beyrut: el-Merkezu's-sekâfiyyü'l-arabî, 1991), 24.

${ }^{49}$ Torusdağ-Aydın, Metindilbilim, 72-73.

50 Özsoy vd., Genel Dilbilim-II, 161.

${ }^{51}$ Halliday-Hasan, Cohesion in English, 288.
} 


\subsubsection{Tekrar/Yineleme (التكرير)}

Tekrar/yineleme, metinde yer alan herhangi bir unsurun bire bir tekrarı; eş, yakın veya zıt anlamlısının tekrarı ya da sözcüklerin genel anlamlı kavramlarla tekrarı şeklinde gerçekleşir. ${ }^{52}$ Kalem Sûresi'nin 7. âyetinde iki defa zikredilen (أعلم) ism-i tafdili bire bir tekrara; aynı sûrenin 34. âyetindeki

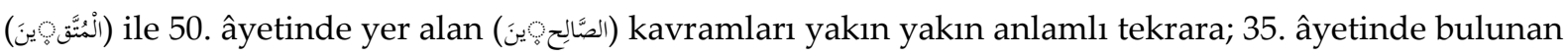

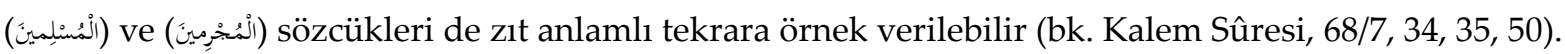

\subsubsection{Eşdizim (المصاحبة)}

Metinlerde sözcüksel bağlaşıklığı temin eden unsurlardan biri de eşdizimsel örüntülerdir. ${ }^{53}$ Eşdizim yoluyla metindeki sözcükler arasında anlamsal yönden uyum sağlanmaktadır. Bu öge metinlerin üretiminde de önemli bir işleve sahiptir. ${ }^{54}$ Nitekim metinlerin oluşumunun sözcüklerle değil, eşdizimli yapılarla temin edildiği belirtilmektedir. ${ }^{55}$ Eşdizim kavramı İngilizce'de collocation terimiyle ifade edilmektedir. Arapça'da ise, ilgili kavramın karşılığ1 hususunda bir görüş birliği yoktur. ${ }^{56}$ Arapça'da eşdizime karşılık olarak الاقتران اللفظي ,قيود التوارد , التضامّ , التلازم , المصاحبة kavramlar1 kullanılmaktadır. Arapça kaynaklarda bunlardan en çok öne çıkanı المصاحبة terimidir. ${ }^{57}$

Eşdizim, bir dilbilim kavramı olarak ilk defa 1750 yılında Amerikalı dilbilimci Zellig Sabbettai Harris tarafından, sözcüklerin dizimine dair çizgisel oluşum özelliği şeklinde kullanılmıştır. ${ }^{58}$ Berke Vardar Eşdizimlilik terimini, "İki ya da daha çok sayıda dil biriminin genellikle aynı dizimlerde yer alması" diye tarif etmektedir. ${ }^{59}$ Başka bir tanımlamaya göre eşdizim, aynı bağlamda aynı kavram alanına ait söz birimlerini kullanarak birbiriyle bağlantılı cümleler oluşturmaktır. ${ }^{60}$ Halliday ve Hasan ise 'bir metinde sözcüklerin birlikte bulunma eğ ilimi' şeklinde bir tanım yapmaktadırlar. ${ }^{61}$ Eşdizim terimini tanımlama çabalarının temel ortak noktası, eşdizimin en az iki sözcükten oluşması ve bu söz birimleri arasında anlamsal açıdan bağlantı olmasıdır. ${ }^{62}$ Günümüzdeki tanımlamalara en yakın tanım olarak ${ }^{63}$ eşdizim, Palmer tarafından "yalın sözcüklerden daha fazlası olan sözcük birliktelikleri” şeklinde ifade edilmiştir. ${ }^{64}$ Tüm bu açıklamalardan hareketle eşdizim, 'birbirleriyle sıkça kullanılan ve aralarında anlamsal bağ bulunan sözcük birlikteliklerinin oluşturduğu yapılar' şeklinde tanımlanabilir. Böylece

\footnotetext{
52 Detaylı bilgi ve örnekleri için bk. Halliday-Hasan, Cohesion in English, 288, 291; Hattâbî, Lisâniyyât, 24-25; Torusdağ-Aydın, Metindilbilim, 78, 84 .

53 Özsoy vd., Genel Dilbilim-II, 162

54 Akşit, "Abdullah b. Revâha'nın Hz. Hamza'nın Şehadetine İlişkin Şiirinde Bağlaşıklık Öğeleri”, Balıkesir Üniv. İlahiyat Fak. Dergisi, 5/ 1, (Haziran 2019), 147.

55 Neticeyi Tayyibe Eken, "Eşdizimlerin Saptanmasına ve Betimlenmesine Yönelik Kuram ve Yaklaşımlar”, Mustafa Kemal Üniversitesi Sosyal Bilimler Enstitüsü Dergisi, 13/33, (Nisan 2016), 31.

56 Daşkıran, “Arap Dilinde Eşdizim ve Arapça Sözlüklerde Eşdizim Sorunu” 2.

${ }^{57}$ Muhammed Ebu'l-Ferec, el-Me'âcimu'l-'arabiyye fî dav'id-dirâsâti 'ilmi'l-luga (Beyrût: Dârü'n-nehdati'l-'arabiyye, 1966), 111.

58 Harold Palmer, Second Interim Report on English Collocations (Tokyo: The relationship between reading comprehension and second language development in a comprehension-based ESL program, 1933, 9-29.

59 Vardar, Dilbilim Terimleri Sözlüğ̈̈, 94-95.

60 Şükran Dilidüzgün, Türkçe Öğretiminde Metindilbilimsel Bağlamda Uygulamalı bir Yaklaşım (İstanbul: İstanbul Üniversitesi, Sosyal Bilimler Enstitüsü, Doktora Tezi, 2008), 78.

${ }^{61}$ Halliday-Hasan, Cohesion in English, 284-286.

${ }^{62}$ Neticeyi Tayyibe Eken, Anlatı Metinlerinde Sözcük Birliktelikleri: Türkçe Üzerine Eğitim-Öğretim Ortamları Hedefli Gözlemler, (Ankara: Ankara Üniversitesi, Sosyal Bilimler Enstitüsü, Doktora Tezi, 2015), 90.

${ }^{63}$ Eken, Anlatı Metinlerinde Sözcük Birliktelikleri: Türkçe Üzerine Eğitim-Öğretim Ortamları Hedefli Gözlemler, 30.

${ }^{64}$ Palmer, First Interim Report on Vocabulary Selection (Tokyo: ESL program, 1931), 4.
} 
bir sözcük diğerine eşdizimsel örüntüleme (aynı kavram alanında kullanılma) yoluyla bağlanarak metindeki sözcüksel bağlaşıklı̆̆ın oluşumuna katkı sağlar. ${ }^{65}$

Eşdizimsel yapılar sözcüklerin anlamını belirlemede de önemli bir işleve sahiptir. Türkçe'de

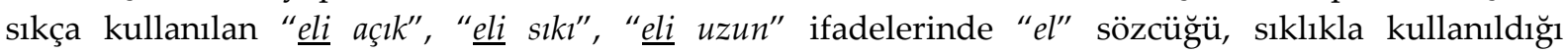
kelimelerle eşdizim oluşturmakta ve birliktelik oluşturduğu sözcüğe göre de anlamı değişmektedir. Bunların yanı sıra Türkçe'deki "temiz kalpli", "katı yürekli", "ağırbaşlı", "kalp kırmak", "tepesi atmak", "sıkboğaz etmek", "yan çizmek" vb. ifadeler de eşdizimli yapılardan meydana gelmektedir.66 Örnek olarak verilen tüm bu sözcük grupları birden fazla kelimeden oluşsa da aynı dizimde yer aldıkları ve birliktelik oluşturdukları için artık tek bir parça haline gelmiştir. Eşdizimli yapılar bu şekildeki veciz ve anahtar kelimelerle metinlerde anlamsal ilişkiler kurarak bağlaşıklığa katkı sağlamaktadır. Eşdizimsel yapılarda sözcüklerin birlikteliği kadar dizilişleri de önem arz etmektedir. Zira söz konusu sözcüklerin dizilişi bozulduğunda ana dilini konuşan kişiye doğal gelmeyecektir. Örneğin Türkçe'deki "gece gündüz" eşdizimi, Arapça'da "يلا ونار", İngilizce'de de "day and night" şeklinde aynı sıralamayla kullanılmaktadır. ${ }^{67}$ Diğer taraftan eşdizim oluşturan sözcüklerin yerine onların eş veya yakın anlamlıları kullanılamaz, bu bir dil hatası olur. Örneğin " ارتكاب الجرمة - suç işlemek" eşdizimindeki " sözcüğü yerine "فرتكاب" ifadesini koymak isabetli bir kullanım olmaz. Bu örnekten de anlaşılacağı üzere, eşdizimsel yapılar arasındaki birliktelik rastgele olmayıp, anlamsal ve gramatikal açıdan aralarında bir iş birliği vardır. ${ }^{68}$

Halliday ve Hasan "Cohesion in English" (İngilizce'de Bağlaşıklık) adlı ortak çalışmalarında, aralarında bir ilişki olmadığı halde sıklıkla bir arada kullanılan sözcüklerin bir işlevi olarak eşdizimlilik olgusunu, yüzeysel bağlaşıklık düzeneklerinin alt bir grubu olarak ele almaktadırlar. ${ }^{69}$ Onlar bazı eşdizimsel birliktelikleri şöyle örneklendirmişlerdir: ıslak-kuru, erkek-kız, emir-itaat, gülümseme-şaka, çaba-başarı, hasta-doktor, kral-kraliyet, gökyüzü-günışı̆̆ı vb. ${ }^{70}$ Verilen bu eşdizim çiftlerinin bir kısmında zıt yapılarla oluşmuş bir ilişki (erkek-kız), bir kısmında üst kavram-alt kavram ilişkisi (gökyüzü-günışığı), bazılarında çağrışım ifade eden ilişki (hasta-doktor), bazılarında da nedensonuç ilişkisi (çaba-başarı) bulunduğu görülmektedir. Buna göre, aynı kavram alanından olabildiği gibi farklı kavram alanına ait sözcükler arasında da çağrışımsal bir ilişki oluşabilmekte ve aynı bağlamlarda bir arada sıklıkla kullanılabilmektedir. ${ }^{71}$

Eşdizim oluşturan yapıların sınıflandırılmasında dilbilimsel açıdan anlam temelli, sıklık temelli ve karma şeklinde üç farklı yaklaşım söz konusudur. ${ }^{72}$ Ancak bu yaklaşımlardan yola çıkarak Arapça metinlerdeki eşdizimli yapıları tasnif ve tespit etmek mümkün gözükmemektedir. Zira devasa bir sözcük hazinesine sahip olan Arap dili, buna bağlı olarak çok sayıda eşdizimsel yapıya da sahiptir. Dolayısıyla Arapça'da hangi sözcüklerin birbirleriyle sıkça kullanıldığını ve birliktelik oluşturduğunu tespit etmek güçtür. Bu nedenle Arap dilinin genel yapısını ve özelliklerini dikkate alarak eşdizim oluşturan yapıları biçimsel özelliklerine göre tasnif etmek daha uygun görünmektedir. $\mathrm{Bu}$ sınıflandırmada eşdizimsel yapılar, eşdizimi oluşturan parçaların şeklî/biçimsel özelliklerine ve

\footnotetext{
65 Torusdağ-Aydın, Metindilbilim, 92.

${ }^{66}$ Daha fazla örnek için bk. Eken, Anlatı Metinlerinde Sözcük Birliktelikleri, 91-94.

${ }^{67}$ Hakkı Suçin, Çeviribilim Öteki Dilde Var Olmak (İstanbul: Multilingual Yayınları, 2007), 127.

${ }^{68}$ Şeyma Gülsüm Önder, Arap Dilinde Eşdizim, (İstanbul: Marmara Üniversitesi, Yüksek Lisans Tezi, 2014), 6.

${ }^{69}$ Halliday-Hasan, Cohesion in English, 284-286; Ayrıca bk. Eken, Anlatı Metinlerinde Sözcük Birliktelikleri, 32.

${ }^{70}$ Bkz. Halliday-Hasan, Cohesion in English, 284-286.

${ }^{71}$ Eken, Anlatı Metinlerinde Sözcük Birliktelikleri, 32.

${ }^{72}$ Bu yaklaşımlar için bk. Eken, Anlatı Metinlerinde Sözcük Birliktelikleri, 51-85.
} 
sözcük türüne göre tasnif edilir. ${ }^{73}$ Böylece Arapça metinlerdeki eşdizimleri tespit etmek isteyen bir araştırmacı, -aşağıda zikredeceğimiz- biçimsel özelliklerden hareketle eşdizimli yapıları daha rahat ve kolay bir şekilde tespit etme imkânı bulacaktır. Bu yapılar (Arapça'da) genel olarak isim-sıfat ( ثقة عمياء aşırı güven), fiil-isim (يستل سيفا - kرئ - beyin göçü) şeklindeki yapıllarda gelir. ${ }^{74}$ Eşdizim oluşturan yapılarla ilgili tasnif türlerinden bazılarını maddeler halinde şöyle sıralamak mümkündür:

1) İsim+Atıf Harfi+İsim (veya ma'tûf aleyh+ma'tûf): السَّماء والأرض (gök ve yer), اليَّلْ وَالنَّهَارِ (gece ve

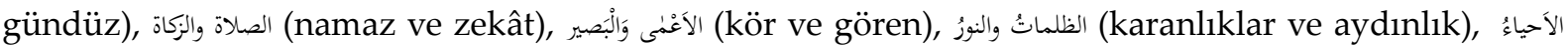
والامواتُ (diriler ve ölüler), المشرق والمغرب (doğu ve batı) vb.

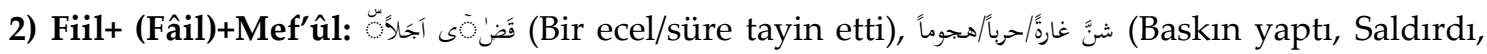
Savaş açtı) gibi.

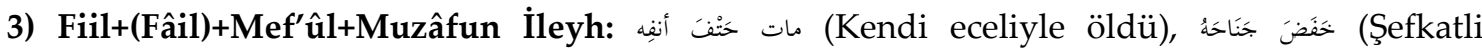

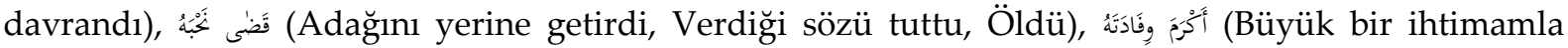
karşılad1) gibi.

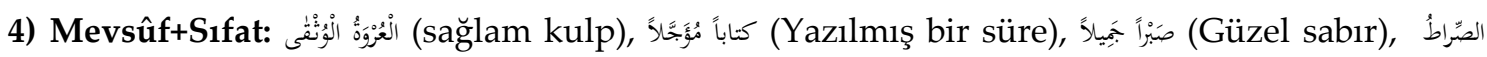

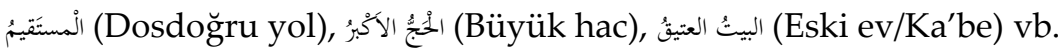

5) Muzâf+Muzâfun İleyh (İsim Tamlaması): آَْل الْبَيْبِ (Ev halk1), أُمّ الكتاب (Kitâbin esas1/Levh-i

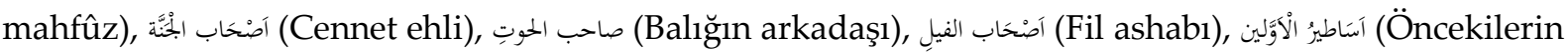
masallar1), حديثُ عهئ (Yeni, Taze, Çiçeği burnunda) vb.

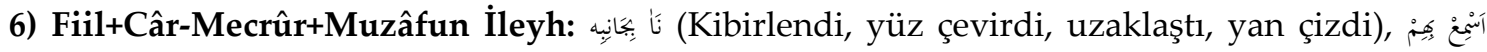
(Ne iyi işitirler) vb.

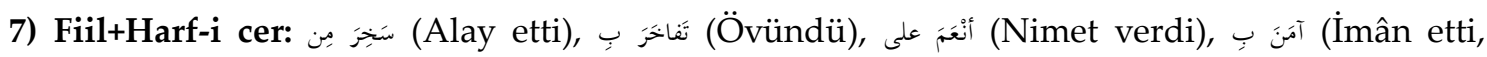
inand1), قام بِ (Yapt1, Yerine getirdi), سلّم على (Selam verdi) gibi.75

8) Harf-i cer+Mecrûr+Muzâfun ileyh: منذ نعومة أظفاره (Çocukluğundan beri), عن بكرة أبيهم (Herkes, Hep beraber, İstisnâsı) gibi.

9) Fiil+ (Fâil)+Hâl: خحرُوا سُحَّدا (Secdeye kapand1lar), خرَّ صَرِيعاً (Yere y1kıld1) gibi.

10) Fiil +(Fâil)+Fiil +(Fâil): سمعنا و أطعنا (İşittik ve itaat ettik), كذّب و عصى (Yalanladı ve isyan etti) gibi. ${ }^{76}$

Arap dilindeki eşdizimsel yapıların tespiti için yapılan bu sınıflandırma, genel bir tasnif olup daha da zenginleştirilmesi mümkündür. Eşdizimler tespit edilirken, bunların sıklıkla bir arada kullanılan ve aralarında anlamsal ilişki bulunan sözcüklerden meydana gelmiş olmasına özellikle dikkat edilmelidir. Zira birliktelik oluşturan her bir yapının eşdizim oluşturduğu söylenemez.

\footnotetext{
${ }^{73}$ Akşit, “Abdullah b. Revâha'nın Hz. Hamza'nın Şehadetine İlişkin Şiirinde Bağlaşıklık Öğeleri”, 148.

${ }^{74}$ Daşkıran, "Arap Dilinde Eşdizim ve Arapça Sözlüklerde Eşdizim Sorunu”, 2.

${ }^{75}$ Harf-i cerlerle (ilgeçler) bileşik bir yapı oluşturan fiiller de eşdizimsel yapıların bir parçası olarak kabul edilmektedir. Çünkü söz konusu harf-i cerler, bu fiillerin ayrılmaz birer parçası haline gelmişlerdir. Bu harfler, fiillerin anlamını da etkilemektedir. Örneğin; رغب في "istemek, arzulamak" anlamına gelirken, رغب عن "yüz çevirmek, istememek" anlamını ifade etmektedir.

${ }^{76}$ Bu tasnifler ve örnekleri hakkında detaylı bilgi için bk. Ferîd Ivaz Haydar, "el-Musâhabetü'l-lafziyye fî şi'ri Şevkî", Mecelletü külliyeti dâri'l-ulûm, 33, (2004), 574-609. Benzer ve farklı tasnifler için ayrıca bk. Daşkıran, "Arap Dilinde Eşdizim ve Arapça Sözlüklerde Eşdizim Sorunu", 3; Önder, Arap Dilinde Eşdizim, 16-39.
} 


\section{Kalem Sûresi'ndeki Eşdizimler}

Arap dilinde eşdizim oluşturan yapıların biçimsel özelliklerine göre tasnif edildiği yukarıda ifade edilmişti. Şimdi eşdizimlerin bu biçimsel temelli tasnifinden hareketle Kalem Sûresi'nde yer alan eşdizimler tespit edilmeye çalışlacaktır.

\section{1. İsim Tamlaması Biçimindeki Eşdizimler}

Sûrede isim tamlaması şeklinde geçen ilk eşdizim, 15. âyette yer alan "öncekilerin masalları"

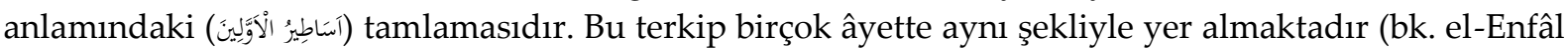
8/31; en-Nahl 16/24; el-Mü'minûn 23/83; el-En'âm, 6/25). (آسَاطئر) kelimesi, "yazmak" anlamina gelen (سطر) kök fiilinden türetilmiş çoğul bir kelime olup, müfredi "üstûr, üstûre, istâr, istîr" şekillerindedir. Bu da "bâtıl olan şeyler, doğru olmayan asılsız haberler, ilginç olaylar, uydurma hikâyeler" gibi anlamlara gelmektedir.77 "الأَوَلِينَ" sözcügüüle birlikte Kur'ân bağlamında "İslâm'dan önceki milletlerin yazdıkları masallar, hikâyeler" manâsını ifade etmektedir. Bu eşdizimin geçtiği âyetlerin hemen hepsinde Kur'ân-1 Kerîm'in ilâhî bir kitap olmadığını ileri süren Mekkeli müşriklerin Hz. Peygamber (s.a.s)'e yönelttikleri sözleri mahiyetinde aktarılmaktadır (bk. el-Furkân, 25/4-6; el-En'âm, 6/25; enNahl, 16/24). Onlar bu (esâtîrü'l-evvelîn) söylemleriyle Kur'ân'ın Allâh kelâmı olmadığını, bir tür hurâfe yığını ve uydurulmuş bir yalan (!) olduğunu, Hz. Peygamber'in bunu, önceki milletlerden yardım alarak yazdığını, dolayısıyla Kur'ân'ın geçmişlerin masallarından ibaret olduğunu iddia ediyorlardı (bk. el-Furkân, 25/4-6). Görüldüğü üzere, Allah'ın emirlerini alaya alan ve Peygamberini asılsız iddialarla itham eden kafir ve müşriklerin mesnetsiz söylemleri bir eşdizim ile özetlenmekte ve bu iddiaları Kur'ân'ın çeşitli yerlerinde çürütülmektedir. Bu anahtar kavramla, inanmayanların karakteristik söylemleri özlü olarak aktarılmakta ve Kur'ân genelindeki ilgili ayetler arasında bağlaşıklık oluşmaktadır.

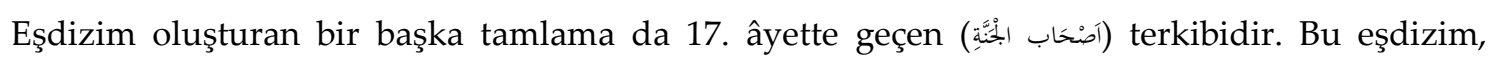
Kur'ân-1 Kerîm'de Kalem Sûresi dışında 12 âyette geçmekte olup, bunların hepsinde de "ölümden sonraki ebedî mutluluk yeri olan cennet ehli" anlamında kullanılmıştır (bk. Yûnus, 10/26; el-A'râf, 7/42-44; el-Ahkâf, 46/14; el-Haşr, 59/20). Fakat Kalem Sûresi'ndeki (年) sözcügüu, lügat anlamiyla kullanılmış olup "bitki ve ağaçlarıyla toprağı örten bahçe"78 demektir. Buna göre sûredeki bu terkip "bahçe sahipleri" anlamındadır. Bu eşdizimle, geçmiş dönemlerde yaşamış ve kendilerine ait verimli bir bahçeleri olan, hasat vakti geldiğinde fakirlerin payını kesen ve bahçenin mahsûlünü sabah erkenden gizlice devşirmeye yemin eden, ancak bu yeminlerine ('Allah izin verirse' gibi) bir kayıt da koymayan, bu sebeple bahçeleri bir afetle yok olan bazı kimselere işaret edilmektedir. ${ }^{79}$ Söz konusu eşdizim yoluyla dikkatler bir noktaya çekilmekte, müteakip ayetlerde de bu anahtar ifadenin içeriği detaylandırılmaktadır. Böylelikle söz konusu eşdizim sayesinde bu tarihi sahne adeta bir tamlama yoluyla tasvir edilmekte, ardından gelen ayetler için çatı kavram rolü üstlenerek konuyla ilgili ayetler arasında bütünsellik oluşturmakta ve sûrenin bağlaşıklığına katkı sağlamaktadır.

\footnotetext{
77 Ahmet Hasan ez-Zeyyât vd., el-Mu'cemü'l-vesît (Kâhire: Mücme'ü'l-lüğati'l-arabiyye, 1960), 1-2, 478; er-Râğıb el-Esfehânî, elMüfredât fî ğarîbi'l-Kur'ân, (y.y., Mektebet-ü Nizâr Mustafâ el-Bâz, ts.), 2/306.

${ }^{78}$ M. Süreyya Şahin, "Cennet", Türkiye Diyanet Vakfı İslâm Ansiklopedisi (İstanbul: TDV Yayınları, 1993), 7/374.

${ }^{79}$ Ebü'l-Berekât Hâfızüddîn Abdullah b. Ahmed b. Mahmûd en-Nesefî, Medârikü't-tenzîl ve hakâikü't-te'vîl, thk. Zekeriyyâ Umeyrât (Beyrût: Dârü'l-kütübi'l-ilmiyye, 2014), 2/ 706; Nâsırüddîn Ebû Saîd (Ebû Muhammed) Abdullâh b. Ömer b. Muhammed el-Beyzâvî, Envârü't-tenzîl ve esrârü't-te'vîl, thk. Mecdî Fethî es-Seyr (Kâhire: el-Mektebetü't-tevfîkiyye, 2012), 2/534.
} 


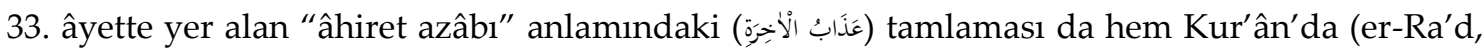
13/34; Tâhâ, 20/127) hem de hadislerde çokça geçen bir eşdizimdir. ${ }^{80}$ Bu eşdizim, adı geçen bahçe sahiplerinin dünyada uğradığı felakete nazaran ahiret azabının daha şiddetli olacağını ifade etmekte, böylelikle muhatabı muhakeme ve mukayese yapmaya sevk etmektedir. Kur'ân-1 Kerîm'in farklı

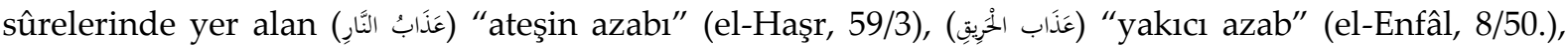
(عَذَاب السَّعِير) "Çılgın ateşin azabı" (el-Hac, 22/4) tamlamaları da "azap" kelimesinin ortak olduğu benzer eş dizimlerdir. Dolayısıyla Kalem Sûresi'ndeki bu eşdizim, cehennemin şiddetini anlatan bu azap türlerini de dolaylı yoldan hatırlatmaktadır.

Diğer bir eş dizim de 34. âyetteki (بَنَّات النَّعْم) ifadesidir. Birçok âyette geçen bu tamlama, üç

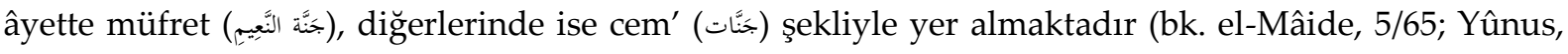
10/9; el-Hac, 22/56; eş-Şuarâ, 26/85; Lokman, 31/8.). "نعيم" sözcüğü, maddî ve manevi açıdan insana

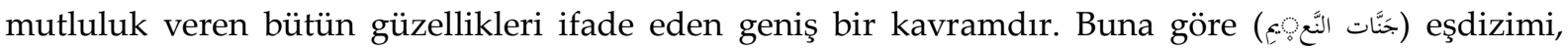
"mutluluklarla dolu cennetler" anlamına gelir. ${ }^{81} \mathrm{Bu}$ eşdizim ile de âhiret ahvalinden olan cennetin güzellikleri ve içindeki nimetler belirtilmekte, bu açıdan söz konusu bu yapı, cennetle ilgili vasıfları

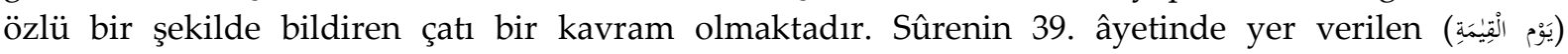
tamlaması da gerek Kur'ân'da (bk. Âl-i İmrân, 3/185; en-Nisâ, 4/87; el-Mâide, 5/36; el-En'âm, 6/12; elA'râf, 7/32; en-Nahl, 16/92; es-Secde, 32/25.) gerekse hadislerde ${ }^{82}$ sıklıkla kullanılan bir eşdizimdir. Dolayısıyla kıyamet, ölüm sonrası hayat, cennet ve cehennem gibi ahiret ahvali ile ilgili konular eşdizimsel örüntülerle özlü bir şekilde ifade edilmiş, ayrıca dünyada isyana dalan inkârcıların uğrayacağı kötü akıbet ile inananlara verilecek mükâfatlar, birbirinin karşıtı olan anahtar kelimelerle (cennet-azap) ifade edilerek ayetler arası bağlaşıklık sağlanmıştır.

48. âyette ise (صَاحِب الُْوِتِ) eşdizimi yer almaktadır. "Balığın arkadaşı" anlamına gelen bu ifadeyle kastedilen kişi, Hz. Yunus (a.s)'dır. Kalem Sûresi'nde, Hz. Yûnus'un kavmine karşı öfkeye kapılıp sabırsızlık göstermesi eleştirilmekte, daha sonra Allah'ın inâyeti ve nimeti sayesinde içine düştüğü sıkıntıdan (balık tarafından yutulması) kurtulduğu bildirilmektedir. Bu âyette Hz. Peygamber (s.a.s)'e, kendisine verilen peygamberlik görevini sabır ve azimle yerine getirmesi emredilmekte, ardından $\mathrm{Hz}$. Yûnus Paygambere atıf yapılarak Rasûlullâh'a, aynı davranışa düşmemesi telkin edilmektedir. Görüldüğü üzere, Hz. Yûnus'un ibretlik kıssası "sâhibu'l-hût" eşdizimiyle zihin dünyasında canlandırılmakta, ardından da dîni tebliğ esnasında maruz kalınan zorluklar karşısında acele etmeyip sabırla mücadele edilmesi gerektiği hatırlatılmaktadır. Nitekim Hz. Yûnus kıssası söz konusu olduğunda genel olarak akla ilk gelen, onun bir balık tarafından yutulduğudur ki, söz konusu eşdizim de sûrede bu rolü üstlenerek bir kıssayı özlü bir şekilde zihinlere yerleştirmektedir. Başka bir sûrede de (el-Enbiyâ, 21/87) buna yakın bir anlam ifade eden (وذا النون) "Zennûn" (balık sahibi) ifadesi de Hz. Yûnus'a işarette bulunan benzer bir kullanımdır.

\section{2. "Fiil+Harf-i Cer+Mecrur" Biçimindeki Eşdizimler}

Sûrede bu türden yer alan ilk eşdizim 7. âyetteki (ضَلَّ عَنْ سَبلهيله cümlesidir. Genel olarak "Allâh'ın yolundan sapmak", "hidâyetten ayrılıp bâtıl ve sapık yollara girmek" gibi anlamlar ifade eden bu eşdizim Yüce Allâh'ın, dosdoğru yolu olarak tavsif ettiği "sırât-1 müstakîm" (el-Fâtiha, 1/6; el-

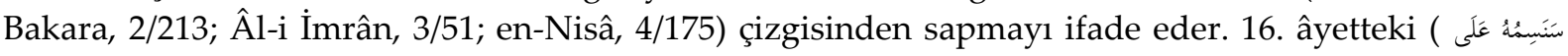

\footnotetext{
${ }^{80}$ Buhârî, "Talâk", 28; "Şehâdât", 21; Ebû Dâvud, es-Sünen, "Talâk”, 27.

${ }^{81}$ Bekir Topaloğlu, “Cennet”, Türkiye Diyanet Vakfi İslâm Ansiklopedisi (İstanbul: TDV Yayınları, 1993 ), 7/376.

82 Buhârî, "Vudû̀", 3.
} 


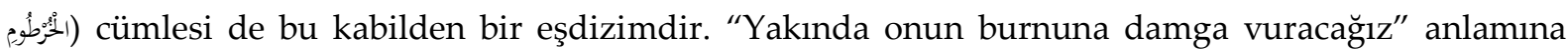
gelen bu cümlede, "burun" (المُرُطُمُم) ifadesinin özellikle zikredilmesi oldukça anlamlıdır. Çünkü yüz bölgesinde, özellikle de burnun üzerinde bulunan herhangi bir darbe veya yara izi, göz önünde bulunan açık bir leke gibi durur ve karşı tarafa çirkin bir görüntü aksettirir. Âyette burnuna damga vurulacağı ifade edilen kişinin Velîd $b$. Muğîre olduğu ifade edilmekte ve onun Bedir savaşında burnuna bir yara darbesi aldığı ve daha sonra bu darbenin burnunda iz bıraktığı nakledilmiştir..$^{83} \mathrm{Bu}$ eşdizimin mecâzi bir anlatım ifade ettiği de vurgulanmıştır. Buna göre söz konusu ifade, sahip olduğu güç ve zenginliği nedeniyle şımarıklık yaparak Allah, peygamber ve kitap tanımayan kimseleri Allah Teâlâ'nın son derece zelil ve perişan edeceğini, gurur ve kibrini kıracağını ifade etmektedir. ${ }^{84}$ Bazı

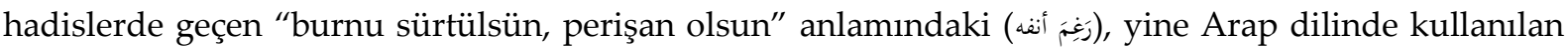

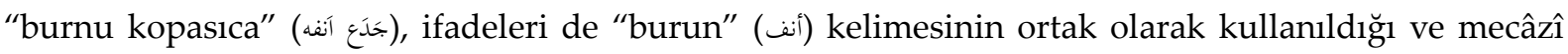
anlatım ifade eden benzer eşdizimlerdir.

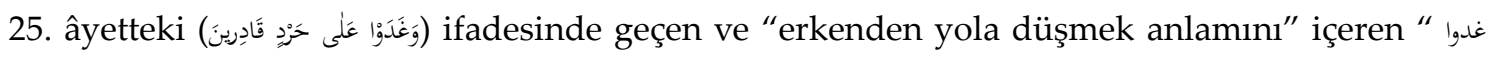

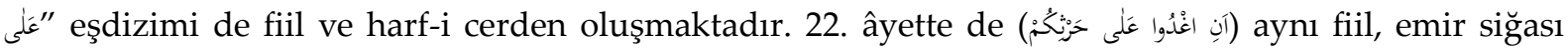
üzere yine (على) cer harfiyle eşdizim oluşturmuştur.

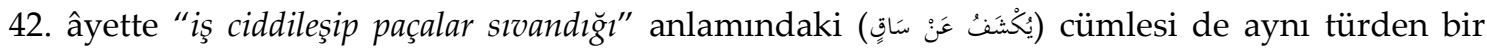
eşdizimdir. Bu ifadede yer alan (كشف) fiili, "perdeyi açmak, bir şeyin üzerindeki örtüyü kaldırmak"; 85

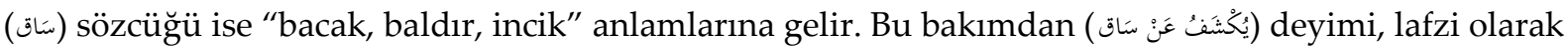
"incikten/baldırdan açılır" anlamına gelmektedir. Bu şekilde lafzî anlamıla geçtiği âyetler de (bk. enNeml, 27/44) bulunmakla birlikte, bu deyimle daha ziyade önemli, güç ve ciddi bir işe girişilmesi yahut bir olayın iyice yaklaşması veya hakikatlerin tüm açılığıyla ortaya çıkması kastedilmektedir. ${ }^{86}$ Söz konusu âyette bu eşdizimle bilhassa kıyâmet gününde yaşanacak korku, dehşet ve sıkıntılar bir

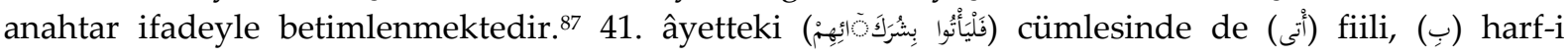
cerriyle "fiil+harf-i cer+mecrûr" biçiminde bir eşdizim oluşturmuştur. Bu fiilin (ب) harfiyle kullanımı oldukça yaygın olup birçok âyette yer almaktadır (bk. el-Bakara, 2/23, 106; Hûd, 11/13; eş-Şuarâ,

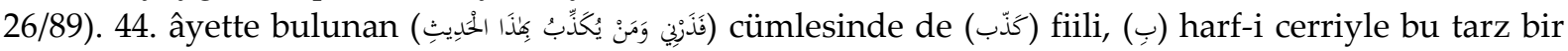
eşdizim oluşturmuştur. (كََّْ (كَّ) fiilinin bu harf-i cerle kullanımı Kur'ân'da oldukça yaygındır (bk. elBakara, 2/39; el-Mâide, 5/10; el-En'âm, 6/157; Yûnus, 10/ 17; el-İsrâ, 17/59; el-Furkân, 25/11; et-Tîn, 95/7.).

Fiil+harf-i cer+mecrur biçiminde gelen başka bir eşdizim de 51. âyetteki "O inkârcılar (...) seni

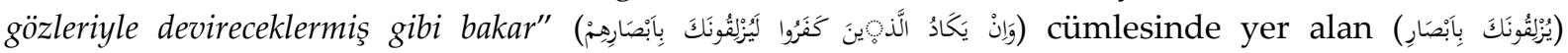
ifadesidir. Bu eşdizim yoluyla, Hz. Peygamber (s.a.s)'den Kur'an'ı dinleyen müşriklerin bakışları etkili oklara benzetilmiş, ona karşı duydukları kin, nefret ve kıskançlık gibi olumsuz duyguları adeta tasvir edilmiştir. ${ }^{88}$ Nitekim müşrikler Hz. Muhammed'i gördükleri zaman, ona karşı duydukları nefret, düşmanlık ve kıskançlık nedeniyle onu gözleriyle oklayıp öldüreceklermiş gibi öfkeyle bakarlardı. ${ }^{89}$

\footnotetext{
${ }^{83}$ Beyzâvî, Envârü't-tenzîl, II, s. 534; en-Nesefî, Medâriku't-tenzîl, II, s. 706.

8484 Hayreddin Karaman vd., Kur'ân Yolu Türkçe Meâl ve Tefsîr (Ankara: DİB Yayınları, 2012), 5/431; Beyzâvî, Envârü't-tenzîl, $2 / 534$.

${ }^{85}$ Ali b. Muhammed es-Seyyid el-Cürcânî, et-Ta'rîfât, thk. Muhammed Siddîk el-Minşâvî (Kâhire: Dârü'l-fadîle, ts.),154.

86 Beyzâvî, Envârü't-tenzîl, 2/537; Ebü'l-Kâsım Mahmûd b. Ömer b. Muhammed el-Hârizmî ez-Zemahşerî, el-Keşşâf an hakâiki'tenzîl ve uyûni'l-ekâvîl fî vucûhi't-te'vîl (Beyrût: Dârü'l-ma'rife, 2009), 1132; Nesefî, Medâriku't-tenzîl, $2 / 708-709$.

${ }^{87}$ Ebu'l-Kâsım Muhammed b. Ahmed İbn Cüzeyy, et-Teshîl li ulûmi't-tenzîl (Beyrût: Dârü'l-kütübi'1-ilmiyye, 1995), 2/475.

${ }^{88}$ Karaman vd., Kur'ân Yolu, 5/439.

89 Zemahşerî, el-Keşşâf, 1133; Beyzâvî, Envârü't-tenzîl, 2/538; Nesefî, Medâriku't-tenzîl, 2/710.
} 


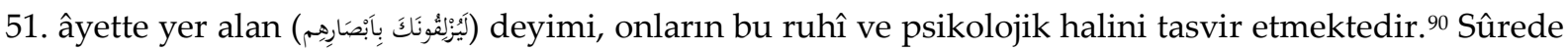
geçen bu âyetlerde fiiller, yaygın olarak birliktelik oluşturdukları cer harfleriyle içinde bulundukları cümlenin birimleri arasında anlamsal ilişkiler kurarak sûrenin bağlaşıklı̆̆ına katkı sağlamıştır. Bu gruba giren eşdizimler daha ziyade içinde yer aldıkları ayet birimleri arasında anlamsal bağlantı kurarak bağlaşıklığı sağlamaktadır. Nitekim fiil veya fiilden türetilmiş isimlerle bileşik bir hâl alan harf-i cerler, içinde bulundukları âyetlerin birimleri arasında hem şekilsel hem de anlamsal açıdan bağlantı kurarak sözcükler arasında bir köprü vazifesi üstlenmektedir.

\section{3. "İsim+Harf-i Cer+Mecrûr" Biçimindeki Eşdizimler}

Sûrede bu türden yalnızca bir eşdizim olup, 11. âyette geçen "laf taşımak" anlamındaki (

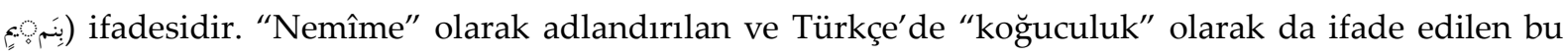
gayr-i ahlâkî davranış tarzı, "bozgunculuğa sebebiyet verecek tarzda bir topluluğun sözünü başka bir

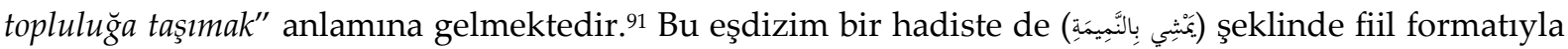
geçmektedir.92 Ayette yer alan (مََّّة) ifadesi, "çokça yürüyüş yapan" anlamında mübalağa ifade eden bir ism-i fâil kalıbıdır. Bu açıdan bakıldığında, insanların arasında laf götürüp getirmek suretiyle bozgunculuğu ve ifsadı adeta meslek haline getiren ve gittiği her yerde başkalarının dedikodusunu yapan kimseler söz konusu eşdizim yoluyla vurgulu bir şekilde ifade edilmiştir. Bu tür eşdizimler de içinde bulundukları ayet birimleri arasındaki bağlaşıklığın oluşmasına katkı sağlamaktadır.

\section{4. "Mevsûf+Sıfat" (Sıfat Tamlaması) Biçimindeki Eşdizimler}

Sûrede "mevsuf+sıfat" şeklinde iki tane eşdizim yer almaktadır. Bunlardan birincisi 3. âyette

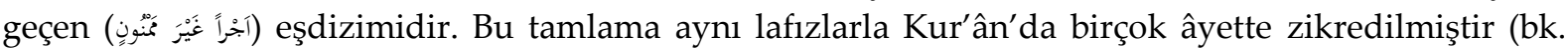
Fussilet, 41/8; el-İnşikâk, 84/25; et-Tîn, 95/6). Kalem Sûresi dışındaki diğer âyetlerde, imân edip iyi davranışta bulunanlara vadedilen kesintisiz mükâfatı; Kalem Sûresi'nde ise, özellikle Hz.

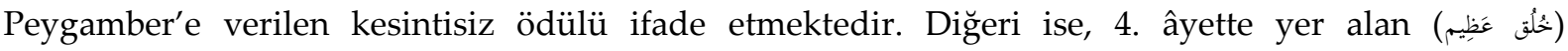
eşdizimidir. "Yüce ahlâk" anlamına gelen bu tamlama, Rasûlullâh (s.a.s)'in sahip olduğu Kur'ân ahlâkını bildirmektedir. (نحُقلق عَخِيم) eşdizimi, Hz. Muhammed (s.a.s)'in -Mekkeli müşriklerin iddia ettiği gibi- kâhin veya mecnun değil, bilakis Allah'ın lutfuna mazhar olmuş üstün bir ahlâka ve yüksek bir kişiliğe sahip, bütün insanlık için her yönüyle mükemmel bir örnek ve güvenilir bir önder olduğunu göstermektedir.93 Dolayısıyla sûrenin başında, müşrik veya kâfirlerin Hz. Peygamber'e yönelttikleri kâhin, mecnun vb. sıfatların asla onunla bağdaşmayacağı, aksine onun Allah'ın nimetleriyle donatıldığı, Kur'ân'ın öngördüğü yaşantıyı en mükemmel tarzda hayatına yansıtarak güzel bir

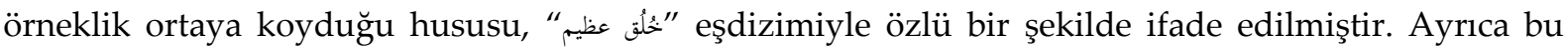
ifadeden sonra o inkarcılar hakkında zikredilen ve yüce ahlakla bağdaşmayan dalkavukluk, yalanlama, sürekli yemin etme, koğuculuk vb. kötü hasletler de zıtlık ilişkisi bağlamında bu eşdizimle ilişkilendirilebilir. Zira ahlak, iyi ve kötü ahlak şeklinde iki kısımda incelenmektedir. Kalem Sûresi'nde de ahlâk-1 hamide demek olan yüce ahlâk kavramı veciz bir şekilde açıklandıktan sonra, bunun karşıtı olan ahlâk-ı zemîme kapsamına giren kötü hasletler de zikredilerek bir konu bütünlügü oluşmuştur. Böylece bir eşdizim yoluyla güzel ahlaka uygun olan tüm faziletli davranışlar Peygamber için ispat edilirken; müşriklerin iddia ettiği yakıştırmalar da ondan nefyedilmiştir. Bu itibarla sûrede

\footnotetext{
${ }^{90}$ Karaman vd., Kur'ân Yolu, 5/439.

${ }^{91}$ Nesefî, Medâriku't-tenzîl, 2/705.

92 Buhârî, "Vudûu", 56.

${ }^{93}$ Karaman vd., Kur'ân Yolu, 5/430.
} 
(iyi veya kötü) ahlakla ilgili olarak zikredilen âyetlerin genel anlamda bu çatı kavramın içinde yer aldığı söylenebilir.

\section{5. “İsim+Atıf harfi+İsim” Biçimindeki Eşdizimler}

Kalem Sûresi'nde bu türden sadece bir eşdizim bulunmaktadır. O da 14. âyette geçen "mal ve evlatlar" anlamındaki (مَال وَبَينَ) ifadesidir. Özellikle bu ikilinin bir arada zikredilmiş olması, çoğu insanın geçici olan bu nimetlere aşırı düşkünlük göstererek, asıl yurt olan âhiret için gerekli hazırlıkları ihmâl etmeleri sebebiyledir (Âl-i İmrân, 3/14). Bazı âyetlerde (bk. el-Kehf, 18/46) aynı lafızlarla geçen bu eşdizim, Kur'ân'da aynı anlamı ifade eden (أمَوَال وَّوَّد) şeklinde çoğul kipleriyle yer almaktadır (bk. el-Enfâl, 8/28; Âl-i İmrân, 3/10; el-Münâfikûn, 63/9; et-Teğâbün, 64/15). İnsanoğlunun, dünyevi nimetlere aşırı ve ölçüsüz bir rağbet gösterdiği takdirde âhirette büyük bir ziyana uğrayacağ hususu, atıf yoluyla eşdizim oluşturan iki unsur üzerinden dikkatlere sunulmaktadır. Böylece söz konusu âyet, eşdizimsel bir örüntüyle hem yüzeysel hem de anlamsal açıdan bağlaşık hale gelmektedir.

\section{6. “Hâl+Fâil” Biçimindeki Eşdizimler}

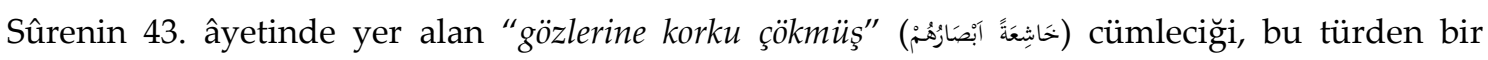

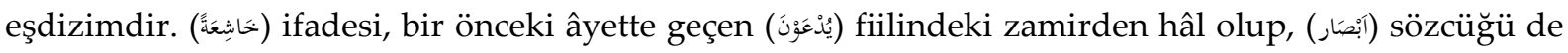
onun fâili konumundadır. ${ }^{94}$ Bu eşdizim, dünyada iken Allâh'a secde etmeyen inkârcıların kıyâmet günündeki sıkıntılı hallerini tasvir etmektedir. Buna göre, kıyamet gününde onların gözlerine korku çökecek, zillet içinde ve perişan bir vaziyette bulunacaklardır. Bu eşdizimin benzer kullanımları başka âyetlerde de yer almaktadır. Örneğin Kamer Sûresi'nde (خَاشع) ism-i fâilinin çoğul kipiyle yine

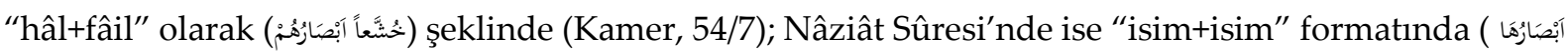
(خَاشِعة biçiminde geçmektedir (en-Nâziât, 79/9). Bu şekildeki benzer eşdizimler Kur'ân genelinde yer alan benzer kullanımları da bir anlamda hatırlatmakta ve konuya bütüncül bir bakış açısı kazandırmaktadır. Bu tür eşdizimler yoluyla, verilmek istenen mesaj zihinde canlandırılmakta, inkârcı ve günahkarların âhiretteki hallerinden bazı kesitler tasviri bir yolla muhataplara iletilmektedir.

\section{7. “Nidâ Harfi+Münâda" Biçimindeki Eşdizimler}

Bu biçimdeki eşdizimin sûrede yalnızca bir örneği olup 31. âyetteki (يَّ وَيْنَ) ifadesidir. "Veyl" sözcügü "çetin azap, rüsvaylık, cehennemde bir vadi, beddua, helâk olma, musibet, felaket" gibi anlamlara gelmektedir. ${ }^{95}$ Üzüntü ve pişmanlık durumlarını ifade etmek için kullanılan bu eşdizim, ${ }^{96}$ umûmiyetle "yazıklar olsun!" "vay haline!" şeklinde tercüme edilmektedir. "Veyl" kelimesi birçok âyette nidâ harfi olan (يَ) ile eşdizim oluşturduğu gibi (bk. el-Enbiyâ, 21/14, 46, 97; Yasin, 36/52; esSâffât, 37/20), "isim+harf-i cer+mecrûr" biçiminde (J) harf-i cerriyle de eşdizim oluşturduğu çok sayıda âyet vardır (bk. el-Bakara, 2/79; İbrâhîm, 14/2; Meryem, 19/37; el-Câsiye, 65/7; el-Mürselât, 77/15, 19, 24, 28, 34, 37, 40, 45, 47, 49; el-Hümeze, 104/1; el-Mâûn, 107/4). Benzeri eşdizim hadislerde de

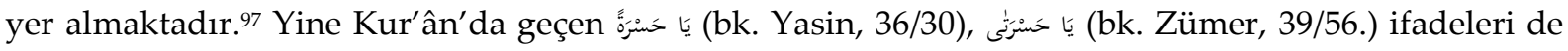
buna yakın anlamlar içeren benzer eşdizimlerdir. Bu türden eşdizimler, önceden yapılanlara duyulan pişmanlık ve üzüntüyü ifade etmektedir. Dolayısıyla okuyucu, bu yapıların bulunduğu yerde

\footnotetext{
${ }^{94}$ Nesefî, Medâriku't-tenzîl, 2/709.

${ }^{95}$ Zeyyât vd., el-Mu'cemü'l-vesît, 1-2, 1119; Karaman vd., Kur'ân Yolu, 5/686; Esfehânî, el-Müfredât, 2/695.

96 Esfehânî, el-Müfredât, 2/ 695.

97 Buhârî, "Cenâiz", 91.
} 
olumsuz bir durumun bulunduğunu kolay bir şekilde anlayabilir. Bu bakımdan "nidâ harfi+münâda" tarzındaki eşdizimler de anahtar birer unsur olma özelliği taşır.

Genel anlamda Kalem Sûresi'ndeki eşdizimsel örüntülere bakıldığında, bunların bir kısmı, içinde yer aldıkları âyetlerin birimleri arasında bağlaşıklığı kurarken (isim+atıf harfi+isim, fiil+harf-i cer, isim+harf-i cer şeklindeki eşdizimler gibi); bir kısmı da sûre genelinde hem dilbilgisel hem de anlamsal açıdan bütünlüğü ve dolayısıyla bağlaşıklığı sağlamıştır. "Balığın arkadaşı, esâtirü'l-evvelîn, yüce ahlak, bahçe sahipleri, gözleriyle devirmek" ifadeleri bu kabilden olan birer eşdizimdir. Bu eşdizimler birer çatı kavram rolü üstlenerek sûreyi oluşturan âyetleri konu düzleminde adeta örmüş, zihinde daha kalıcı ve anlaşılır kılmaya da katkı sağlamıştır.

\section{Sonuç}

Metin-dilbilimsel ölçütlerden biri olan bağlaşıklık, çeşitli ögelerle sağlanmaktadır. Bu ögelerden biri de sözcüksel bağlaşıklık olup tekrar ve eşdizimlerle sağlanmaktadır. Eşdizim ise, birbirleriyle sıkça kullanılan ve aralarında anlamsal ilişki bulunan anahtar ifadeler olup en az iki sözcükten meydana gelen sözcük birliktelikleridir. Kalem Sûresi'nde en çok yer alan eşdizim türleri sırasıyla fiil+harf-i cer+mecrûr ( 7 tane), isim tamlaması ( 5 tane) ve sıfat tamlaması ( 2 tane) biçimindeki yapılardır. Bunların dışındaki eşdizim türlerinden de birer tane yer almaktadır. Bu eşdizimsel örüntüler, siyak-sibak ilişkisi kurarak hem sûreyi oluşturan âyet birimleri arasında hem de sûre genelinde bağlaşıklığın oluşmasını sağlamıştır. Bunun yanı sıra söz konusu örüntüler, Kur'ân genelinde zikredilen benzer kullanımlarla çağrışım yapmak sûretiyle âyetlerin derin yapısını anlama noktasında da önemli katkılar sunmuştur. Sûredeki balığın arkadaşı, eskilerin masalları vb. bazı eşdizimlerin, geçmişteki birtakım tarihî hâdiseleri betimleyici ve etkileyici bir tarzda dikkatlere sunması büyük ölçekli yapıyla (bağdaşıklık) ilgili önemli fikirler vermektedir. Ayrıca eşdizimsel yapılar, metinlerdeki birtakım durum ve olayları özlü olarak ifade etmeleri yönüyle de anahtar unsurlar olma özelliğine sahiptir.

Eşdizimsel birliktelik oluşturan örüntülerin bazıları, içinde yer aldıkları âyetlerin birimleri arasında bağlaşıklığı sağlarken (fiil+harf-i cer, isim+harf-i cer şeklindeki eşdizimler gibi); bazıları ise sûre genelinde hem dilbilgisel hem de anlamsal açıdan bağlaşıklığı temin etmektedir. "Balığın arkadaşı, yüce ahlak, bahçe sahipleri" ifadeleri bu türden eşdizimlerdir. Bu eşdizimler birer çatı kavram veya temel başlık gibi bir rol üstlenerek sûreyi oluşturan âyetleri konu düzleminde adeta örmüş gibidir. Örneğin; sûrede bu türden olan "bahçe sahipleri" eşdizimi zikredildikten sonra tarihi bir hâdiseye işaret edilmekte ve takip eden âyetlerde bu çatı kavramın muhtevası hakkında bilgi verilmektedir. Dolayısıyla yaklaşık 17 âyet ile muhtevası açıklanan tarihi bir olay adeta iki sözcükten müteşekkil olan "ashâbü'l-cenne" eşdizimiyle özetlenmiş olmaktadır. Bu türdeki diğer eşdizimler de benzer roller üstlenerek hem sûre genelinde bütünsellik sağlamakta hem de Kur'ân genelinde aynı kavramlarla ilişkili başka âyetlerle bağlantı kurmaya yönelterek konuya bütüncül bir bakış kazandırmaktadır. Kalem Sûresi'ndeki bu ve benzeri eşdizimsel örüntüler yoluyla, geçmişteki birtakım tarihî hâdiseler betimleyici ve etkileyici bir tarzda dikkatlere sunulmakta, ölüm sonrası hayat tasvir edilmekte ve aynı hadiselerin benzer eşdizimlerle geçtiği diğer ayet ve sûreler arasında anlamsal açıdan bir irtibat kurulmaktadır.

Kalem Sûresi'ndeki eşdizimsel örüntüler sûrede bağlaşıklığın oluşmasını temin ettiği gibi, siyak-sibak ilişkisi kurarak hatta Kur'ân genelindeki bağlamını dikkate alarak âyetlerin derin yapısını anlamada da önemli katkılar sağlamaktadır. Gerek müstakil olarak ayetler içi bağlaşıklığı sağlayan gerekse konu bağlamında bütünsellik oluşturarak sûre genelinde birer çatı kavram işlevi gören eşdizimsel örüntüler, okuyucuyu Kur'ân genelinde zikredilen benzer eşdizimlerle de anlamsal ilişkiler kurmaya sevk etmektedir, yani çağrışımsal bir ilişki kurmaktadır. Böylece gerek Kur'ân'ı 
okuyup ezberlemede gerekse anlayıp yorumlamada bu anahtar ifadeler ciddi kolayliklar sağlamaktadır. Ayrıca eşdizimler olayları özlü olarak anlatma, ayetler arası mukayese ve muhâkeme yapma ve dikkatleri bir noktaya toplama açısından da bütüncül bir bakış açısı kazandırmaktadır.

Metinlerin oluşturulma amacı, muhatabı bilgilendirme ve sağlıklı bir iletişim kurmaktır. Bu da ilgili metnin birimlerinin kendi içinde bağlaşık ve tutarlı olmasına bağlıdır. İşte bu amaca hizmet eden metindilbilim de metinlere parçacı ve literal yaklaşmanın önüne set çekerek, metin içi bağlantıları kuran unsurları ve bir metni metin yapan anlamsal ilişkileri bütünsellik ilkesi çerçevesinde ele almayı gerekli görmektedir. Söz konusu yöntemin, Arapça bir metin olan Kur'ân'a veya diğer dillerdeki herhangi bir metne uygulanmasının faydalı ve tutarlı sonuçlar ortaya koyacağı söylenebilir. Bu itibarla Kur'ân'ı metindilbilimsel yöntemle okumanın ve bu türden çalışmalara ağırlık vermenin, sağlıklı ve bütüncül bir Kur'ân anlayışı açısından faydalı olacağını düşünmekteyiz.

\section{Kaynakça}

Akşit, Eyup. “Kur'an-1 Kerim'in Bazı Ayetlerinde Zamir Gelmesi Gereken Yerde İsmin Getirilmesi ve Bunun Nedenleri". Dokuz Eylül Ünüversitesi Illahiyat Fakültesi Dergisi, 48, (Aralık 2018), 43-76.

Akşit, Eyup. "Abdullah b. Revâha'nın Hz. Hamza'nın Şehadetine İlişkin Şiirinde Bağlaşıklık Öğeleri”. Balıkesir Üniversitesi İlahiyat Fakültesi Dergisi, 5/1, (Haziran 2019), 127-156.

Alan, Yusuf. Lisan ve İnsan. İzmir: TÖV Yayınları, 1. Basım, 1994.

Ayata Şenöz, Canan. Metindilbilim ve Türkçe. İstanbul: Multilingual Yayınları, 1. Basım, 2005.

Aydın, Mehmet. Dilbilim El Kitabı. İstanbul: 3F Yayınları, 2. Basım, 2007.

Aksan, Doğan. Her Yönüyle Dil -Ana Çizgileriyle Dilbilim. Ankara: TDK Yayınları, 2007.

Aksan, Doğan. "Kelime Bilimi ve Anlambilimi Ölçülerinden Yararlanarak Bir Yazı Dilinin Eskiliğini Saptama Yolları I: Kavram Alanı-Kelime Ailesi İlişkileri ve Türk Yazı Dilinin Eksikliği". Türk Dili Araştırmaları Yıllığı Belleten 1971, Ankara: TDK Yayınları, TTK Basım Evi, 1989.

Beyzâvî, Ebû Saîd Abdullâh b. Ömer b. Muhammed. Envârü't-tenzîl ve esrârü't-te'vîl. thk. Mecdî Fethî es-Seyr, 2 Cilt. Kâhire: el-Mektebetü't-tevfîkiyye, 2012.

Buhârî, Muhammed b. İsmail. el-Câmiu's-Sahîh. thk. Kâsım es-Semmâ'î er-Rufâ'î, 4 Cilt. Beyrût: Dârü'lErkam, ts.

Cürcânî, Ali b. Muhammed es-Seyyid. et-Ta'rîfât. thk. Muhammed Sıddîk el-Minşâvî, Kâhire: Dârü'lfadîle, ts.

Coşkun Ögeyik, Muhlise. Metinlerarasılık ve Yazın Eğitimi. Ankara: Anı Yayınları, 2. Basım, 2008.

Daşkıran, Yaşar. "Arap Dilinde Eşdizim ve Arapça Sözlüklerde Eşdizim Sorunu”. Journal of Islamic Research, 26/1, (Ocak 2016), 1-9.

De Beaugrande, R. Alain - Dressler, W. Ulrich. Introduction To Text Linguistics. London: Longman Linguistics Library, 1981.

De Saussure, Ferdinand. Cours de Lingistique Generale / Genel Dilbilim Dersleri. çev. Berke Vardar, 1. Basım, İstanbul: Multilingual Yayınları, 2001.

Dilidüzgün, Şükran. Türkçe Öğretiminde Metindilbilimsel Bă̆lamda Uygulamalı bir Yaklaşım. İstanbul: İstanbul Üniversitesi, Sosyal Bilimler Enstitüsü, Doktora Tezi, 2008. 
Ebu'l-Ferec, Muhammed. el-Me'âcimu'l-'arabiyye fì dav'id-dirâsâti 'ilmi'l-luga. Beyrût: Dârü'n-nehdati'larabiyye, 1966.

Eken, Neticeyi Tayyibe. Anlatı Metinlerinde Sözcük Birliktelikleri: Türkçe Üzerine Eğitim-Öğretim Ortamları Hedefli Gözlemler. Ankara: Ankara Üniversitesi, Sosyal Bilimler Enstitüsü, Doktora Tezi, 2015.

Eken, Neticeyi Tayyibe. "Eşdizimlerin Saptanmasına ve Betimlenmesine Yönelik Kuram ve Yaklaşımlar". Mustafa Kemal Üniversitesi Sosyal Bilimler Enstitüsü Dergisi, 13/33, (2016), 28-47.

Esfehânî, er-Râğıb. el-Müfredât fi ğarîbi'l-Kur'ân. Mektebet-ü Nizâr Mustafâ el-Bâz, ts.

Ebû Dâvud es-Sicistânî, Süleymân b el-Eş'as. es-Sünen. Beyrût: Müessesetü'r-risâle nâşirûn, 2015.

Halliday, M.A.K. - Hasan, Ruqaiya. Cohesion in English. London: Longman Group Limited, 1976.

Hattâbî, Muhammed. Lisâniyyâtü'n-nass: Medhalün ilâ insicâmi'l-hitâb. Beyrut: el-Merkezu's-sekâfiyyü'larabî, 1991.

Hengirmen, Mehmet. Dil bilgisi ve Dilbilim Terimleri Sözlüğ̈̈. Ankara: Engin Yayınları, 1. Basım, 1999.

İbn Cüzeyy, Ebu'l-Kâsım Muhammed b. Ahmed. et-Teshîl li ulûmi't-tenzîl. 2 Cilt. Beyrût: Dârü'lkütübi'l-ilmiyye, 1995.

İmer, Kâmile vd. Dilbilim Sözlü̆̆̈̈. İstanbul: Boğaziçi Üniversitesi Yayınları, 2. Basım, 2011.

Karaman, Hayreddin vd. Kur'ân Yolu Türkçe Meâl ve Tefsîr. 5 cilt. Ankara: DİB Yayınları, 4. Basım, 2012.

Karataş, Yusuf. Söylembilim ve Arapça. Çanakkale: Onsekiz Mart Üniversitesi İlahiyat Fakültesi Yayınları, 2009.

Kıran, Zeynel - Eziler Kıran, Ayşe. Dilbilime Giriş. Ankara: Seçkin Yayınları, 5. Basım, 2006.

Kocaman, Ahmet. Dilbilim Temel Kavramlar Sorunlar Tartışmalar. Ankara: Dil Derneği Yayınları, 1. Basım, 2006.

Martınet, Andre. İşlevsel Genel Dilbilim. çev. Berke Vardar, İstanbul: Multilingual Yayınları, 1. Basım, 1998.

Melîke, İmâran - Vesîle, Bû Suveyra. el-İttisâk ve'l-insicâm fî sûrati'l-Mücâdele: Dirâsetün fì dav'i lisâniyyâti'n-nass. Becâye: Abdurrahman Mîra Üniversitesi, Yüksek Lisans Tezi, 2016/2017.

Nesefî, Abdullah b. Ahmet b. Mahmut. Medârikü't-tenzîl ve hakâikü't-te'vîl. thk. Zekeriyyâ Umeyrât, 2 Cilt. Beyrût: Dârü'l-kütübi'l-ilmiyye, 2014.

Önder, Şeyma Gülsüm. Arap Dilinde Eşdizim. İstanbul: Marmara Üniversitesi, Yüksek Lisans Tezi, 2014.

Özkan, Bülent. “Metindilbilimi, Metindilbilimsel Bağdaşıklık ve Haldun Taner'in 'Onikiye Bir Var' Adlı Öyküsünde Metindilbilimsel Bağdaşıklık Görünümleri”. Çukurova Üniversitesi Sosyal Bilimler Enstitüsü Dergisi, 13/1, (Haziran 2004), 1-18.

Özsoy, A. Sumru vd. Genel Dilbilim - II. (Edt. A. Sumru Özsoy-Zeynep Erk Emeksiz), 2 Cilt. Eskişehir: Anadolu Üniversitesi Web Ofset, 2013. 
Palmer, Harold. Second Interim Report on English Collocations. Tokyo: The relationship between reading comprehension and second language development in a comprehension-based ESL program, 1931.

Palmer, Harold. First Interim Report on Vocabulary Selection. Tokyo: The relationship between reading comprehension and second language development in a comprehension-based ESL program, 1931.

Subaşı Uzun, Leyla. Orhon Yazıtlarının Metindilbilimsel Yapısı. Ankara: Simurg Yayınları, 1. Basım, 1995.

Suçin, Hakkı. Çeviribilim Öteki Dilde Var Olmak. İstanbul: Multilingual Yayınları, 2007.

Şahin, M. Süreyya. “Cennet”. Türkiye Diyanet Vakfı İslâm Ansiklopedisi. 7/376-386. İstanbul: TDV Yayinları, 1993.

Topaloğlu, Bekir. "Cennet". Türkiye Diyanet Vakfı İslâm Ansiklopedisi. 7/376-386. İstanbul: TDV Yayınları, 1993.

Türkçe Bilgi. Erişim 1 Kasım 2021. http://www.turkcebilgi.com/ansiklopedi/dilbilim

Vâfî, Ali Abdulvâhid. İlmü'l-luğa. Mısır: Nehdatu Mısr, 2004.

Vardar, Berke. Açıklamalı Dilbilim Terimleri Sözlüğü̈. İstanbul: Multilingual Yayınları, 2002.

Zemahşerî, Ebü'l-Kâsım Mahmûd b. Ömer b. Muhammed el-Hârizmî. el-Keşşâf an hakâiki'tenzîl ve uyûni'l-ekâvîl fî vucûhi't-te'vîl. Beyrût: Dârü'l-ma'rife, 2009.

Zeyyât, Ahmet Hasan vd. el-Mu'cemü'l-vesît. 2 Cilt, Kâhire: Mücme'ü'l-lüğati'l-arabiyye, 1960.

Zeyd, Semîha Evlâd. el-İttisâku'n-nassiyyu: Âleyâtuhu ve vesâiluhu, el-Mevsimu'l-câmi'iyy, Yüksek Lisans Tezi, y.y., 2016. 